\title{
Cooperation by Treaty: The Role of Multilateral Powers*
}

\author{
Karolina M. Milewicz ${ }^{\dagger} \&$ Duncan Snidal ${ }^{\ddagger}$
}

\begin{abstract}
Who supports multilateral treaties and who doesn't? We offer a systematic account of treaty ratification patterns paying particular attention to different states' roles in international legal cooperation in relation to the United States' ratification behavior. We argue that states' ability to influence the terms of treaties and their acceptance increases their incentives for treaty ratification. Multilateral powers - states which are powerful and independent from the US - support multilateral legal cooperation because this offers them an opportunity to shape treaty content. Their engagement in multilateral treaties is strongest when the United States does not lead. Other states that are weak and/or dependent cannot greatly affect treaties and are therefore less supportive of them but are subject to US pressure. An empirical analysis of states' decisions to ratify prominent postwar multilateral treaties covering a wide range of global issues supports our argument. We conclude with broader implications for future international cooperation.
\end{abstract}

Keywords: multilateralism, multilateral treaties, international cooperation, power, independence, ratification, US exceptionalism.

Word count: 10,456 (plus 3,890 online appendix included here.)

*We thank Daniel Abebe, Manfred Elsig, Julia Gray, Tom Hale, Noel Johnston, Emily Jones, Robert Keohane, Andrew Kydd, Walter Mattli and Kristopher Ramsay, anonymous reviewers and Jon Pevehouse for helpful comments and suggestions. Earlier versions of the paper were presented at the EPSA meeting 2013 in Barcelona, the APSA meeting 2013 in Chicago, the ASIL Midyear Meeting and Research Forum 2014 in Chicago, and the Global Economic Governance seminar, University of Oxford in 2015.

${ }^{\dagger}$ University of Oxford, University College, karolina.milewicz@politics.ox.ac.uk

${ }_{\ddagger}^{\ddagger}$ University of Oxford, Nuffield College, duncan.snidal@politics.ox.ac.uk 


\section{Introduction}

Interstate cooperation takes a variety of institutional forms. Sometimes it operates through international organizations, sometimes through formal agreements and sometimes through tacit understandings. Multilateral treaties are one such vehicle of international cooperation. ${ }^{1}$ They are used to provide a wide range of collective goods from international security to human rights to environmental protection. $^{2}$ The 1968 Nuclear Non-Proliferation Treaty limits the spread of nuclear weapons; the 1989 Convention on the Rights of the Child addresses important issues regarding the treatment of children, and the 1987 Montréal Protocol protects the ozone layer. In short, when states have problems that cannot be resolved through individual state action or bilateral agreements, they often turn to multilateral treaties. Yet not all states are equally important in shaping multilateral treaties. Here we address the role of powerful states - including but not restricted to the most powerful state - in achieving interstate cooperation through treaty ratification.

A variety of factors that determine states' willingness to commit to treaties have been identified. ${ }^{3}$ Decisions to ratify depend on policy preferences, ${ }^{4}$ domestic politics, ${ }^{5}$ legal system, ${ }^{6}$ regime type,${ }^{7}$ reputational ${ }^{8}$ or normative benefits,${ }^{9}$ treaty design, ${ }^{10}$ and international diffusion mechanisms. ${ }^{11}$ Although sometimes implicit in these analyses, surprisingly little attention has been paid to states' influence in

\footnotetext{
${ }^{1} \mathrm{~A}$ treaty is "an international agreement concluded between States in written form and governed by international law, whether embodied in a single instrument or in two or more related instruments". Art.2(1)(a), Vienna Convention on the Law of Treaties 1969. For a broad theoretical account of multilateral cooperation see the symposium on multilateralism in International Organization, (Ruggie 1992), especially articles by Kahler and Caporaso, and also Martin 1992.

${ }^{2}$ Kaul, Conceição, Le Goulven et al. 2003.

${ }^{3}$ Pollack 2015.

${ }^{4}$ Downs, Rocke, and Barsoom 1996; Simmons 2009; and Lupu Forthcoming.

${ }^{5}$ Haftel and Thompson 2013; and Kelley and Pevehouse Forthcoming.

${ }^{6}$ Goodliffe and Hawkins 2006.

${ }^{7}$ Neumayer 2002; and Vreeland 2003.

${ }^{8}$ Simmons 2000.

${ }^{9}$ Kelley 2007.

${ }^{10}$ von Stein 2008.

${ }^{11}$ Bernauer, Kalbhenn, Koubi et al. 2010.
} 
the treaty-making process.

We argue that states' influence in shaping treaties - determined by their power and independence - creates incentives for ratification. Power is the ability to shape treaty terms and press for its acceptance; independence is the ability to pursue one's own interests without being subject to pressure by others. The United States is the extreme case with its extraordinary ability to push for treaties and influence other states to support them; it also has demonstrated an ability to exercise its influence outside of the treaty framework (even without ratifying it). We focus here on powerful and independent states other than the US that have significant influence on the adoption and operation of treaties but which, unlike the US, can only influence the treaty through ratification. We label those states multilateral powers. We expect them to be particularly active ratifiers and to take the lead especially when the United States does not participate (by not ratifying or only ratifying slowly). By contrast, if the US decides to participate, multilateral powers are less important to the treaty process and so ratify at a lower rate. Other states that are less powerful and/or less independent than multilateral powers have less leverage and are therefore less supportive of treaties irrespective of the US involvement - although they may be subject to US pressure to follow its lead. Thus, contrary to those who see multilateralism as a tool of the strong ${ }^{12}$ and others who see it as a weapon of the weak, ${ }^{13}$ we show that it can be a strategy of the multilateral powers and expect them to be central to the outcome of international cooperation.

We begin with the presentation of our argument regarding how the power and independence of a state influences its participation in multilateral cooperation. We test our claim about the role of different states in cooperation using a data set of the most important post-war multilateral treaties. An event history analysis of treaty ratification confirms our conjecture that a group of powerful and independent

\footnotetext{
${ }^{12}$ Ikenberry 2000.

${ }^{13}$ Kagan 2003.
} 


\section{Multilateral Cooperation through Treaties}

There are many ways to address collective action problems in international cooperation. Multilateral treaties provide important legal instruments of international cooperation used to resolve collective action problems among states. Some create new multilateral institutions; others contribute to existing international regimes; yet others address more specific collective purposes. Although they are not always fully effective, states sign and ratify treaties because they believe they will change their collective behavior in ways that benefit the international community and themselves. Because ratification is a legally binding commitment to obligations that entail both sovereignty and compliance costs, states have individual incentives not to accept treaties. ${ }^{14}$ This creates a second-order collective action problem where states prefer to free ride rather than ratify, but the treaty process generates

\footnotetext{
${ }^{14}$ We focus on ratification rather than signature because it is more costly as well as a more significant step in making a legal commitment. Signature does not bind a state to a treaty, although it indicates intent to consider it seriously for ratification and not to undermine it in the meantime. Art. 18, Vienna Convention on the Law of Treaties 1969. Signature is a way station to ratification giving a state time to seek domestic approval and to pass necessary domestic legislation to give effect to the treaty. But it is in the process of ratification that governments directly face the costs of political opposition. Finally, states that are not signatories can only join through "accession" or "adoption" which is equivalent to ratification.
} 
a common commitment and assurance that helps overcome this. The logic is that of Schelling's $k$-group ${ }^{15}$ whereby a sufficient number of cooperators can benefit from joint action, as is often reflected in treaty "entry into force" requirements aimed at ensuring sufficient participation. ${ }^{16}$ This outcome remains susceptible to defection, however, and so may need support through exogenous factors including reputational, normative and social incentives.

We focus here on how the treaty process shapes states' individual incentives to support it. Importantly, the benefits and costs of a treaty for each state vary with its exact terms. For example, an arms control agreement might exempt certain categories of weapons, a trade agreement might cover only certain products, or an environmental treaty might define its targets in ways that advantage certain states. Ratification brings a continuing voice in the treaty regime, ${ }^{17}$ and is typically a prerequisite to inclusion in the Conference of the Parties or similar governing bodies which deal with interpretation and implementation of the treaty after its entry into force and which provide a forum for further developments within or beyond the treaty. ${ }^{18}$ If the treaty creates or is governed by a formal international organization, ratification typically gives membership and voting rights. Thus ratification provides states with continuing opportunities to shape the treaty to their advantage.

A state's ability to affect the terms and governance of a treaty depends on its power and on its independence. Larger, more powerful states are usually more

\footnotetext{
${ }^{15}$ Schelling 1978.

16 "Entry into force" clauses protect ratifying states from being obligated under an international treaty unless and until enough other states have also ratified. These clauses typically depend on the number of ratifying states but sometimes are calibrated to the treaty content (e.g., by requiring ratification by states composing a certain share of the activity) in order to protect states from being lonely ratifiers. Art.24, Vienna Convention on the Law of Treaties 1969. Some treaties have entry into force clauses that are closely attuned to power and capacity considerations. For example, the Comprehensive Test Ban Treaty requires ratification by all 44 Annex 2 states (i.e., those with nuclear reactors at the time of negotiation) before coming into force.

${ }^{17}$ Art.40(2), Vienna Convention on the Law of Treaties 1969.

${ }^{18}$ These bodies often have alternative names such as Assembly of the Parties (Rome Statute), Meeting of the Parties (Montréal Protocol) or Ministerial Conferences (World Trade Organization).
} 
important to the solution of the problem at hand; they have more resources for addressing it and have greater diplomatic capacity. ${ }^{19}$ This gives them greater leverage in the treaty process and therefore on the terms of the treaty, which makes them more likely to ratify it. It also gives them more continuing influence on the treaty after entry into force. But a state's ability to influence a treaty depends also on its ability to pursue its own interests without being pressured by other states. A state that is not independent but subject to influence from others will not be as effective in shifting treaty terms and operations to its favor. ${ }^{20}$ Independent states are better positioned to advance their own interests.

Thus it is the conjunction of power and independence that is most important: In order to shape treaties to its interests, a state must have both the power to act and the independence to pursue its own interests. We label states that are both powerful and independent as multilateral powers for convenience in the discussion below. However, multilateral power is not a category but the end of a continuum ranging from states that are low in power and independence to states that are relatively high in both. ${ }^{21}$

Although we stress that multilateral power is a continuum in both our theory and our statistical analysis, for heuristic purposes we introduce the logic of participating in interstate cooperation in terms of three categories: the United States as the exceptional state, the multilateral powers, and weak and/or dependent states. The basic puzzle we are addressing is captured in Table 1 showing the ratification rates of major post-war multilateral treaties by these three representative groups.

\footnotetext{
${ }^{19}$ We use a broad conception of power that goes beyond military capability to include soft power considerations such as socio-economic capacity. We discuss the operationalization of power in more detail in subsection 3.2 below.

${ }^{20}$ We focus particularly on independence from the US for reasons that will be apparent below.

${ }^{21}$ We use this term rather than "great power" - which is too narrowly focused on a small number of military powers and which excludes other states that are important to international cooperation - or "middle power" - which excludes great powers and often carries additional conceptual baggage. Roughly speaking, states in the G8, and to a lesser extent those in the G20, have significant multilateral power, although there are major variations within these groups (e.g., Canada and Mexico are much more dependent on the US). Figure 1 below shows the range of power, independence and their combinations in terms of our operationalizations. In the estimation, we capture this by including power and independence as an interaction.
} 
US behavior in international cooperation is reflected in its very low rate of treaty ratification when compared to other countries. While the US ratified only 29 of the full sample of the 66 treaties, the multilateral powers on average ratified 53.4 treaties (when approximated by the G8-US) or 50.8 treaties (when approximated by the G20-(US\&EU)). Weak and/or dependent states (approximated in the table by the non-G20 states) ratified only 44.3 treaties on average. This pattern is explained by our argument regarding the interaction of power and independence across these states, which we demonstrate in terms of continuous variables below.

\begin{tabular}{llc}
\hline Group of state & Represented by & \# rat. \\
\hline Exceptional state & US & 29 \\
Multilateral powers & G8-US & 53.4 \\
\multirow{2}{*}{ Weak and/or dependent states } & G20-(US\&EU) & 50.8 \\
& non-G20 & 44.3 \\
\hline
\end{tabular}

Table 1: Ratification rates.

Notes: \# rat.: average number of ratifications. G8-US excludes the US and G20-(US\&EU) excludes the US and the EU. The table is based on the full sample of 66 treaties in our data set spanning a wide range of issue areas. The data are described in more detail in section 3 . separately in the analysis below. It is an outlier in both theory and practice. While hegemonic stability theory ${ }^{22}$ has empirical shortcomings, theoretically it usefully highlights the unique role of the "hegemon" in promoting international cooperation. When US preferences are aligned with the preferences of other states, it is positioned to take the lead on cooperation and others are positioned to follow. This has been echoed in Madeleine Albright's memorable invocation of the US as the "indispensable nation" and in recent analyses of monetary hegemony ${ }^{23}$ and unipolarity. ${ }^{24}$ While never truly "hegemonic" in the sense of being able to "pass"

\footnotetext{
${ }^{22}$ Kindleberger 1973; and Keohane 1984. Snidal 1985 provides a theoretical critique of hegemonic stability theory that foreshadows the multilateral powers argument presented here.

${ }^{23}$ Norrlof 2010; and Cohen 2015.

${ }^{24}$ Brooks and Wohlforth 2008; 2015/16; and Monteiro 2014.
} 
This exceptional role of the US in international treaty-making is well-illustrated by the case of the Rome Statute on the International Criminal Court. The US played a major role during negotiations and - as a signatory - continued to influence the development of the treaty even without ratifying it. Despite intense domestic opposition, President Clinton explained his preference for signing the Rome Statute by arguing that "[w]ith signature, we will be in a position to influence the evolution of the court, without signature, we will not". ${ }^{30}$ But American influence continued even after President Bush "unsigned" the treaty in 2002. The US used extraordinary outside pressure to limit the International Criminal Court's (ICC) implications for the US by concluding Bilateral Immunity Agreements with over one hundred states to prevent US citizens from being transferred to ICC jurisdiction without US agreement. The US initially threatened sanctions on states that did not agree and it worked aggressively through the UN Security Council to limit the ICC's authority. ${ }^{31}$ Subsequently, the Bush administration softened its stand and tacitly supported ICC activities in Darfur; the Obama administration has actively engaged with the ICC even while remaining outside of it. While this is a stark case, it illustrates how the US can play a major role in shaping, drafting and signing treaties that it ultimately refuses to ratify and then use its general power to maintain significant influence over the treaty.

Thus, we distinguish between two situations regarding US behavior: one where the US shares preferences with other states and uses its power to take the lead in international cooperation (thereby allowing others to slack); and another where the US has divergent preferences and does not ratify so that it falls on others to take the lead.

Multilateral Powers: Although other states rarely have such extreme influence without actually joining a treaty, states that are powerful and independent (i.e.,

nizations operates both through formal rules and through informal channels. Stone 2011.

${ }^{30}$ Quoted in Scott 2012, 177.

${ }^{31}$ American Non-Governmental Organizations Coalition for the International Criminal Court 2008 . 
multilateral powers) can have significant influence by participating in a treaty. By working together, such states have the ability to cooperate in bringing a treaty to fruition - if they can overcome their incentives to free ride. ${ }^{32}$ The more capacity a state has to be an important contributor to an international agreement and the more independence it has from the US, the more influence it can have over the course of negotiations and subsequent treaty developments. Thus the treaty process provides a propitious forum for multilateral powers to shape international governance. They have strong incentives to ratify a treaty in order to both ensure its success and to maintain continuing influence within it. Their influence is likely to be especially great if the US does not ratify the treaty since that makes them more important to both its success and continuing operation. Conversely, multilateral powers' influence on the treaty is diminished whenever the US takes the lead role in ratifying the treaty and influences it from the inside; the participation of the multilateral powers is no longer as necessary, they must compete with the US for influence and so are increasingly tempted to free ride.

Weak and/or dependent states: By contrast, states that are not powerful and/or not independent have less influence. Such states lack the capacity to make much difference to the success of a treaty and/or the independence to push for their own positions within the treaty. Because they have little influence on the treaty, they have less incentive to ratify and greater incentives to free ride. ${ }^{33}$ However, they may be susceptible to pressure from the US to ratify because their participation plays a role in a treaty coming into force and adds to its legitimacy. ${ }^{34}$

\footnotetext{
${ }^{32}$ Again, our point is not that the US can literally "do it alone" since it too needs cooperative partners. But the US is better positioned to organize cooperation than are multilateral powers who, in turn, are better positioned than weak and dependent states. Conversely, the $k$-group logic does not require all multilateral powers to cooperate but only a sufficient number.

${ }^{33}$ These states may participate in international treaties for other reasons not addressed here: considerations of appropriateness (Finnemore and Sikkink 1998), incentives to develop a reputation as good international citizen (Simmons 2000; and Neumayer 2002) or to "lock in" domestic policies against potential future reversals (Moravcsik 2000; Vreeland 2003; and 2008). Such factors determine the "base rate" of ratification that underlies our analysis. Overall, weak and/or dependent states participate less in multilateral treaties, as reflected in their lower ratification rates shown in Table 1.

${ }^{34}$ Of course, other states - including former colonial powers, large trading partners, major aid
} 
Overall, weak and/or dependent states participate in international treaties at typically lower rates (and for other reasons) than multilateral powers as they are unlikely to greatly affect the level or form of cooperation. ${ }^{35}$

Hypotheses: This leads to a relatively simple set of connected hypotheses: 1 . Multilateral powers ratify at a higher rate than weaker, less independent states; 2. When the US does not ratify a treaty, multilateral powers have higher rates of ratification than when the US does ratify a treaty; 3 . The impact of US ratification (or non-ratification) of a treaty is indeterminate for weak and/or dependent states except insofar as they are subject to its pressure to ratify. In summary, multilateral powers are strong supporters of multilateral treaties and they will take the lead especially when the US does not participate.

\section{Data analysis}

We expect multilateral powers to be particularly relevant for treaties that are salient and costly to adopt. The more there is at stake, the more likely a state is to participate in order to influence the treaty content to its own advantage. Thus, we test our argument on a data set consisting of states' ratifications of major multilateral treaties adopted between 1945 and 2008 and ratified by 2010. Our treaty sample builds on the Institute for Agriculture and Trade Policy (IATP) treaty database which identifies such "prominent" multilateral treaties; we extend the sample to include post-2005 treaties as well as a small number of other key multilateral treaties not covered in the IATP sample. ${ }^{36}$ Following the IATP crite-

providers, common members of key regional organizations, and so forth - may be able to pressure weak states that are dependent on them to ratify (or not), but we focus on the US as the only state with widespread influence of this sort.

${ }^{35}$ The exception is when a large group of weak and/or dependent states organizes itself to press for specific treaty provisions as in the case of the International Convention on the Protection of the Rights of All Migrant Workers and Members of their Families negotiations. Lönnroth 1991. This is a rare occurrence as witnessed by collective action failures among such states in the G77 or in GATT/WTO negotiations.

${ }^{36}$ Institute for Agriculture and Trade Policy 2005. For a list of treaties see Table 3, Appendix A. We made the following modifications to the IATP database of 43 treaties: 1) We excluded the 
ria, we include binding international agreements that require the explicit consent of states through ratification; we exclude softer forms of international law such as recommendations, codes of conduct or memoranda of understanding. We also restrict our sample to treaties that involve substantive additions to existing international law - they go beyond simple adjustments or amendments to previous treaties. All included treaties are universal in two senses: 1. participation is open to all recognized states as defined by UN membership, and; 2. they are of global reach - we exclude treaties that are open to all states in terms of membership but have a regional or plurilateral focus. All included treaties are public international law instruments; we exclude private international law instruments (e.g. created through the Hague Conference of Private International Law or the International Institute for the Unification of Private Law - UNIDROIT). Finally, our sample covers seven major areas of global governance, including environment (15), rule of law (5), human rights (18), humanitarian law (3), labor law (7), security (13) and new security (5). The resulting sample includes 66 multilateral treaties addressing a wide variety of collective action problems, and we believe it offers a compre-

International Labour Office Forced Labour Convention C29 (1930), because it was adopted before our period of analysis, and the Treaty on the Limitation of Anti-Ballistic Missile Systems which is not a multilateral agreement but a bilateral treaty between the US and the former Soviet Union. 2) We updated the IATP database to include post-2005 treaties with five subsequent core human rights instruments (the 2006 Optional Protocol to the Convention against Torture, the 2006 International Convention for the Protection of All Persons from Enforced Disappearance, the 2006 Convention on the Rights of Persons with Disabilities and its 2006 Optional Protocol, and the 2008 Optional Protocol to the International Covenant on Economic, Social and Cultural Rights) and one security treaty: the 2008 Convention on Cluster Munitions. 3) We added the 1948 Genocide Convention to the core human rights treaties, three rule-of-law treaties (1945 UN Charter; 1961 Vienna Convention on Diplomatic Relations, and the 1986 Vienna Convention on the Law of Treaties between States and International Organizations (IOs) or between IOs), four environmental treaties (1973 Convention on International Trade in Endangered Species of Wild Fauna and Flora, the 1979 Convention on the Conservation of Migratory Species of Wild Animals, the 1985 Vienna Convention of the Protection of Ozone Layer, and the 1999 Basel Protocol on Liability and Compensation for Damage Resulting from Transboundary Movements of Hazardous Wastes and their Disposal), six security treaties (the 1997 International Convention for the Suppression of Terrorist Bombing, the 2005 International Convention for the Suppression of Acts of Nuclear Terrorism, the 1963 Treaty Banning Nuclear Weapons Tests in the Atmosphere, in Outer Space and Under Water, and the 1980 Convention on Prohibition or Restriction on the Use of Certain Conventional Weapons and the five Protocols thereto), and finally we added five "new security" treaties (the 2000 Convention against Transnational Organized Crime with its three Protocols and the 2003 Convention Against Corruption). 
${ }^{37}$ Bernauer, Kalbhenn, Koubi et al. offer a much larger data set covering 255 environmental treaties. Many treaties in that data set do not meet our selection criteria: not all treaties provide for universal participation - some of the treaties are plurilateral rather than multilateral; many have a regional rather than global focus; and some do not substantially change the body of international law but are primarily amendments to existing practice. Bernauer, Kalbhenn, Koubi et al. 2010. A comparative analysis of the treaties in our data set with those in the Bernauer at al. data set shows that treaties in the Bernauer et al. data set are less contentious as reflected in a shorter average time to ratification.

${ }^{38}$ Therneau and Grambsch 2000.

${ }^{39}$ Andersen and Gill 1982. This approach is particularly suited to the situation of mutual independence of observations within a subject. See Box-Steffensmeier and Zorn 2002, 1073-74; and Therneau and Grambsch 2000, 185-86. It assumes that multiple events for any particular subject are conditionally independent; the risk of experiencing the event for a given subject is unaffected by any earlier event that happened to the same subject. State A can ratify treaty X without or before ratifying treaty $\mathrm{Y}$, and state $\mathrm{B}$ can ratify treaty $\mathrm{Y}$ without or before ratifying treaty X. However, the timing of ratification can be subject to group effects (by states or by treaties); see footnote 41 . 

5 jackknife. $^{42}$

analysis or the termination of a state. ${ }^{40}$ Whether the ratification event actually occurred is indicated by a binary status variable. We account for correlated groups of observations (non-independence of multiple ratifications per state) by clustering on states, ${ }^{41}$ and applying robust sandwich variance estimators based on a grouped

\subsection{Explanatory variables}

We capture the role of multilateral powers in international treaty-making through the interaction of Power and IndePendence (Power*IndePendence). Because our concern is state influence in the treaty process, we conceptualize Power broadly (going beyond military resources or market size). Our PowER index is composed of 10 variables reflecting three dimensions of power: military, economic, and social and human capital. The first two variables capture the military dimension and traditional geo-political power: military expenditure (in thousands of current year US\$), and military personnel (in thousands). The next four variables cover the economic dimension and a state's material capacity to support and affect international cooperation: energy consumption (in thousands of coalton equivalents), total trade (in millions of current US\$), GDP per capita (log), and government expenditure (in current US\$). The final four variables address the social and human capital dimension capturing less direct elements of influence related to soft power: literacy rate (as percentage of adult population), number of physicians (per 1,000 people), total population (log), and population ages 15-64 (as percentage of total population). A more detailed overview of the component variables of the POWER index (including definitions, sources and measurements)

\footnotetext{
${ }^{40}$ Count data consists of multiple records and is set up as annual intervals to include timevarying covariates. The data for a given state-treaty is presented as multiple rows of "observations", each of which applies to an interval (start, stop].

${ }^{41} \mathrm{We}$ also tested for whether ratification patterns are subject to treaty-group effects (i.e. states' ratifications are more homogenous for any given treaty) by clustering the observations on treaties. This alternative procedure did not alter the results in any substantial ways.

${ }^{42}$ Box-Steffensmeier and Jones 2004, 158.
} 
is provided in Table 4 (Appendix A). To handle missing observations, we used several data sources and applied statistical imputation techniques. As a rule, we extrapolated and interpolated the data employing generalized additive models. ${ }^{43}$ After a graphical examination of all variables for all states, we applied linear fits to individual cases. ${ }^{44}$

To construct the Power index, we applied factor analysis for time series. ${ }^{45}$ Separate time-series factor models were estimated for all constituent variables and states. We then averaged the factor loadings for each variable over all states. Based on the linear combinations of the mean factor loadings and the standardized observations, we calculated a single Power index. We also report results based on alternative power measures including the Composite Index of National Capability (CINC) ${ }^{46}$ and Gross Domestic Product (GDP) ${ }^{47}$ as well as the individual dimensions of the Power measure under Robustness checks in Appendix B.

We operationalize INDEPENDENCE in relation to the United States which is the state in the strongest position to pressure other states (as discussed above). We measure state INDEPENDENCE by trade relations with the US, following Kirshner's argument on how asymmetric relations shape a dependent state's foreign policy. ${ }^{48}$ Balanced trade relations - where each state accounts for roughly the same share

\footnotetext{
${ }^{43}$ Wood 2006.

${ }^{44}$ To this end we made the following significant transformations: For GDP per capita (log) we used as a basis real GDP per capita from Penn World Table (PWT) 6.2 (Heston, Summers, and Aten 2006), and interpolated and extrapolated the data with estimates of GDP growth rate per capita from World Development Indicators (WDI) (World Bank 2007). If neither PWT 6.2 nor WDI data was available, we used GDP per capita, deflated by GDP deflator from WDI for the basis year of the PWT 6.2 estimates. To estimate government expenditures, literacy rate (\% of adult population) and physicians (per 1,000 people), we used WDI data. If not available, we imputed estimates from the Cross-national Times-series Data Archive. Banks 2006. For the estimation of total population (log) we first used PWT 6.2 data, and then imputed WDI estimates.

${ }^{45}$ Gilbert and Meijer 2005.

${ }^{46}$ Correlates of War Project 2005.

${ }^{47}$ World Bank 2007.

${ }^{48}$ Kirshner 2003. This is an extension of Hirschman 1945. See also Keohane and Nye 1977; and Gilpin 2011. We use Barbieri's measure of independence but check it against an alternative measure of trade dependence. Barbieri 1996. Other measure such as aid or investment dependence would be useful supplements but only trade (in)dependence is systematically available for all states for our time period.
} 
1 of the other's trade - indicate independence; conversely, when one state's trade is 2 much more heavily oriented towards the other than vice versa, then the former state 3 is less independent of the other. As an alternative operationalization we use trade 4 dependence (DEPEnDENCE) measured as states' total trade with the dominant 5 state as a proportion of its GDP. We report those results under Robustness checks 6 (Appendix B).

7 Our focus is on the contemporaneous interaction of states' power and independence which we show for three points in time (1950, 1975 and 2000) in Figure 1. 9 The numbers are in relation to the US which is not shown. Unsurprisingly, there 10 is variation in the location of states over time but the overall pattern remains fairly stable. A relatively small number of states are both powerful and independent $^{49}$ whereas the growing majority of countries are relatively non-powerful and vary in degrees of independence. Only a few countries (note especially Canada, and Mexico in recent years) are fairly powerful but not highly independent. We check for the importance of particular groupings of states in the Robustness checks (Appendix B).

\footnotetext{
${ }^{49}$ Our focus here is not on individual states, but on the group of states roughly occupying the upper right quadrants of Figure 1 which as multilateral powers are potential $k$-group members. See also Table 1 where we use two alternative groupings as proxies for the multilateral powers.
} 

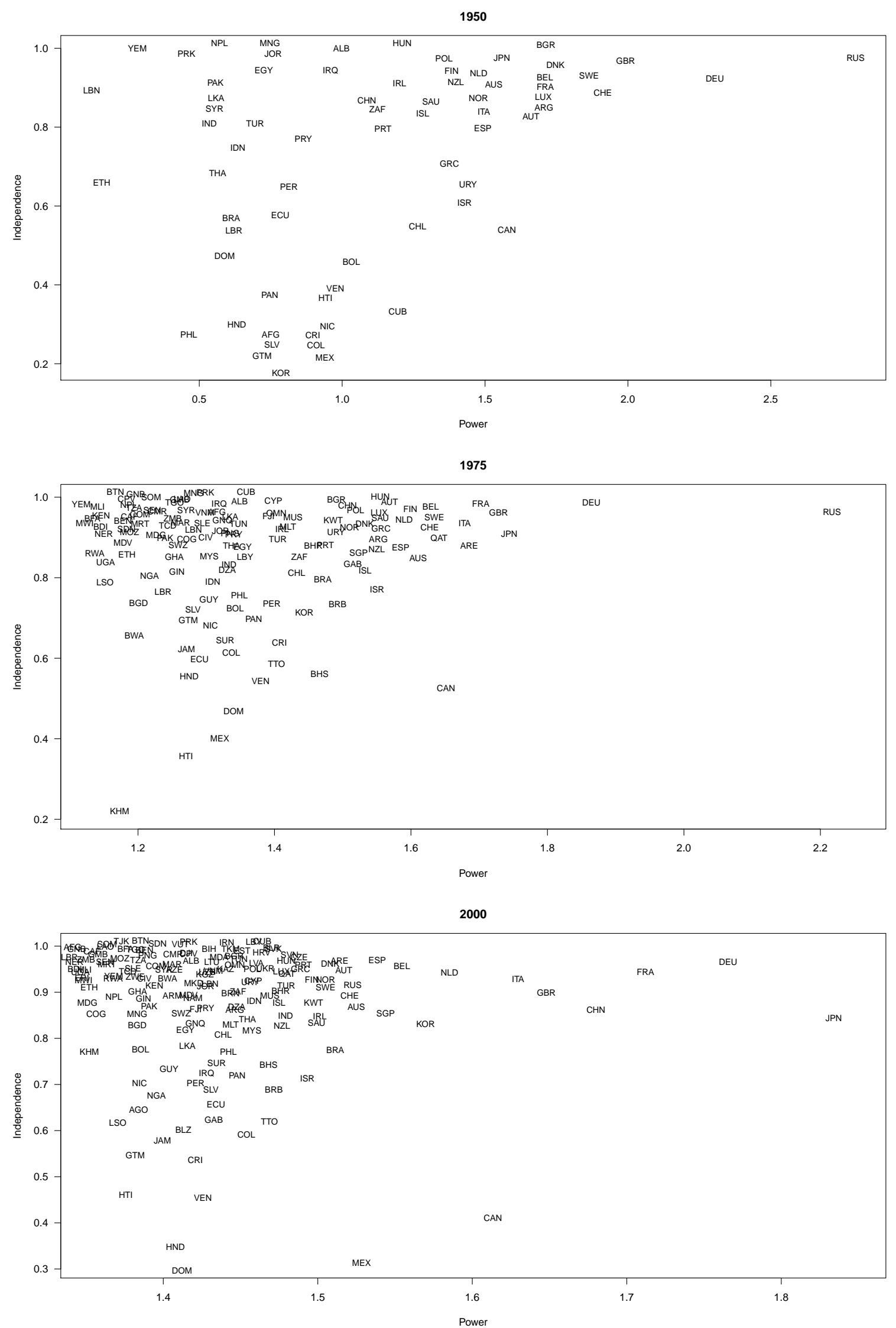

Figure 1: States' Power and IndePendence for 1950, 1975 and 2000 (excluding US).

Note: The variables are in relation to the US, and both axes are rescaled to best depict the data range for each point in time. The three-letter country codes are defined in ISO 3166-1. 
We control for several related and plausible explanations. First, we consider the effect of the domestic regime type (democracy versus autocracy). Democratic states are more likely to support multilateral treaties, as the content of such agreements often is more in accord with their domestic political values. To measure domestic regime type, we employ the polity2 score from the Polity IV index (Democracy). ${ }^{50}$ We also control for the effect of State AgE on ratification. New states which became sovereign through either decolonization or the breakup of the Soviet Union show a high rate of treaty ratification because they are eager to demonstrate their commitment to international rules. We also include a categorical variable for treaty issue areas. We distinguish between RULE OF LAW (as the reference category), Human \& Labor Rights, Security and Environment. For an overview of all explanatory variables and their descriptive statistics see Tables 6 and 5 (Appendix A). In the Robustness checks (Appendix B) we report on models controlling for other effects in addition to those presented in the tables, including colonial past, religious denomination, treaty signature, geographic diffusion of international norms, and different groupings of countries such as the G8, the G20, Europe and new democracies. Overall, in our empirical analysis, we follow Achen's ART approach and keep the models as simple as possible by focusing on the two main explanatory variables and their interaction term. ${ }^{51}$ Fuller description of control variables and results are provided in Table 6, and Appendices B and C.

\subsection{Methods}

We use Cox proportional hazards regression models with the modified partial likelihood for right-censored and left-truncated data. ${ }^{52}$ Fixed right-censoring applies to all states which have not ratified a particular treaty by the end of 2010. Cases of random right-censoring include Czechoslovakia (state termination in 1992), the

\footnotetext{
${ }^{50}$ Marshall and Jaggers 2007.

${ }^{51}$ Achen 2002.

${ }^{52}$ Tableman and Kim 2004.
} 
Socialist Federal Republic of Yugoslavia (terminated in 1991), the German Democratic Republic (1990), Zanzibar (1964) or South Yemen (1989). Left-truncation is caused by delayed entry. ${ }^{53}$ For example, successor states to Yugoslavia such as Croatia and Serbia and former colonies could ratify treaties only after they became sovereign. While a model modified for censored observations allows for the possibility that time to ratification varies across countries, a model adjusted for left-truncated observations further incorporates a consideration of the historical sequence of treaties (i.e., the date a treaty becomes available for ratification depends not only on its date of adoption but also on the state's entry into the data set).

The Cox proportional hazards regression model estimates hazard ratios for the variables discussed above. The hazard ratio ${ }^{54}$ is the exponential of the regression coefficient $(\exp (\operatorname{coef}))$ in the model. A hazard ratio $(\mathrm{HR})$ of 1 indicates that a variable has no effect. A ratio greater than 1 indicates an increase in the rate of ratification (positive impact), and a ratio less than 1 indicates a reduction in the rate of ratification (negative impact). Any statement that a state is more likely to ratify is implicitly with respect to a given year, and is also a statement that the state ratifies more rapidly. ${ }^{55}$

\subsection{Results}

Table 2 presents the Cox proportional hazards regression models for ratification decisions by 199 states for 66 multilateral treaties from 1945 to 2010. Since not all explanatory variables are available for the entire period and all states, the number of observations varies across the models. Furthermore, in some models, we treat

\footnotetext{
${ }^{53}$ Klein and Moeschberger 2003.

${ }^{54}$ The proportional hazards assumption requires the hazard ratio to be independent of time. A test for constancy of the coefficients based on scaled Schoenfeld residuals indicates that this assumption is met by all covariates.

${ }^{55}$ The statistical analysis was computed with R Development Core Team 2014, survival R package version 2.37-4 (Therneau 2015).
} 
the US decision to ratify, and its speed of ratification, as a parametric condition for other states' ratification decisions.

We present six models offering a fuller interpretation of our major explanatory interaction defined in terms of Power*IndePEndence. Models 1 and 2 are based on the full sample of 66 treaties. Model 1 includes Power and IndePEndence, as well as the central interaction of Power*IndePENDENCE. Model 2 adds the effects of Democracy and State Age, as well as issue areas. Since all these controls behave as expected and do not change the main results, we discuss them in Appendix C along with other control variables that do not modify our results.

As a reminder: To assess the effect of a variable included in an interaction term, we must simultaneously take into account the exponentials of the coefficient $(\exp (\operatorname{coef}))$ not only of the interaction term but also of its constituent variables. (It is not appropriate to interpret coefficient size or direction in isolation.) To do this, we assume a fixed value for one variable (e.g. IndEPEndEnCE), and then calculate the effect of a one-unit-increase in the other variable (e.g. PowER) ${ }^{56}$ Model 1 displays a statistically significant effect for POWER*INDEPENDENCE. Its constituent variable POWER has a negative impact lowering a state's propensity to ratify (with a hazard ratio - exponential of coefficient or exp(coef) - less than 1) for values of INDEPENDENCE below 0.51, and a positive impact otherwise; INDEPENDENCE has a negative impact for POWER values below 1.33, and a positive impact otherwise. In terms of our argument, this makes complete sense. A state

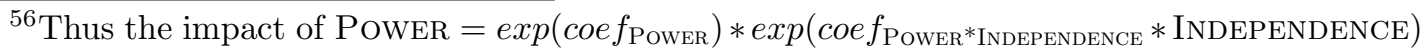
for a given value of INDEPENDENCE.
} 


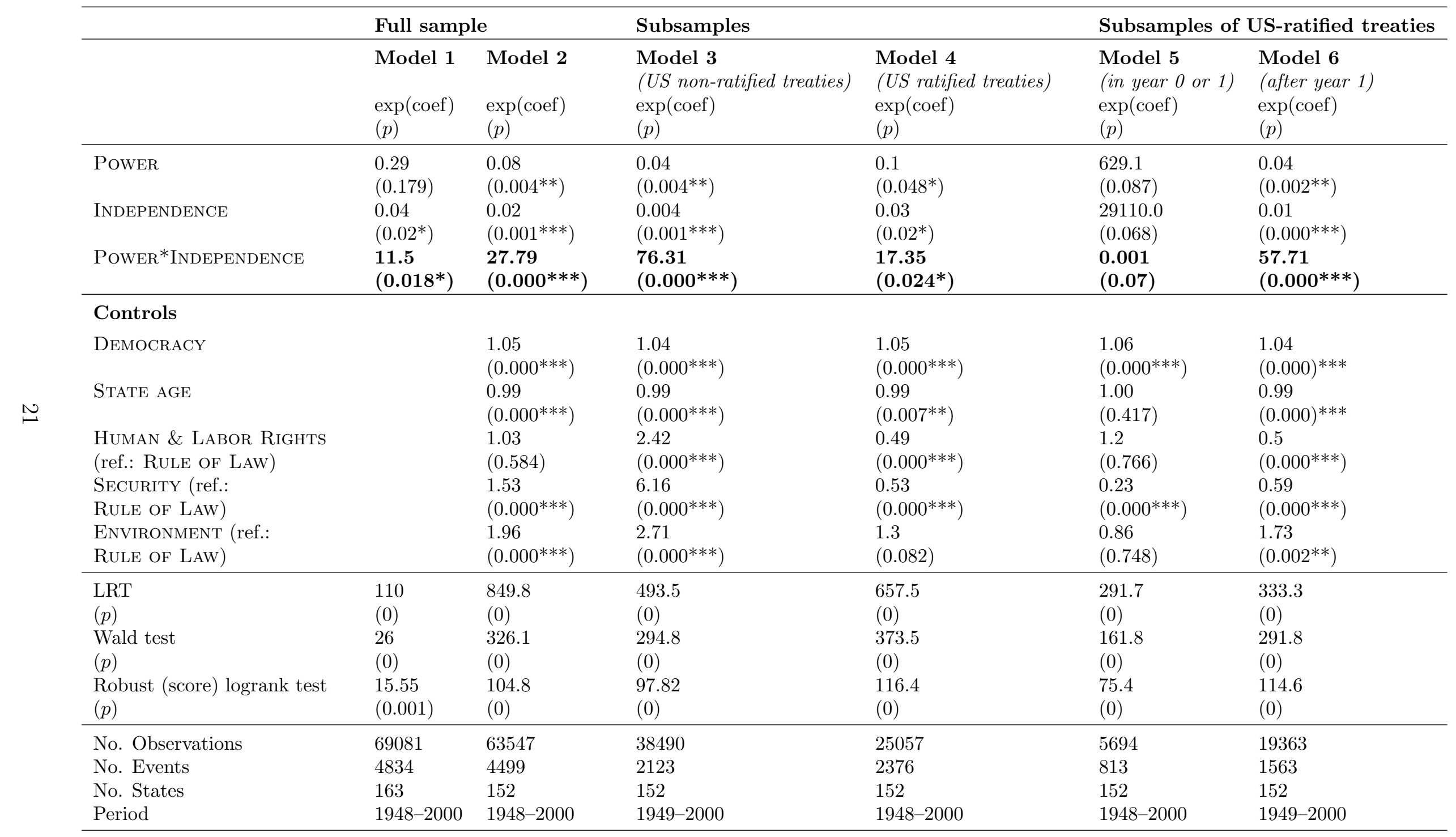

Table 2: Cox proportional hazards regression models.

Notes: Each cell entry $[\exp (\operatorname{coef})]$ is the exponential of the coefficient which is the hazard ratio (HR). The likelihood ratio test assumes independence of observations within a cluster (country); the Wald and robust score tests do not. ${ }^{* * *} p|z|=<.001,{ }^{* *} p|z|=<.01,{ }^{*} p|z|=<.05$. 
that is powerful but dependent has less independent leverage and so has less incentive to participate; similarly, a state that has little power will have limited leverage even if it is independent. But states that are both powerful and independent (multilateral powers) have strong incentives to participate in multilateral treaties. ${ }^{57}$

Model 2 sharpens the results by including the controls, but does not greatly change them. It further clarifies that POWER*INDEPENDENCE is a robust predictor of ratification. The coefficient is substantively large as we discuss below. The constituent variables Power and IndePendence continue to work as above - a result that is consistent throughout our analysis with one important exception "that proves the rule" (as shown in model 5). In sum, both models confirm hypothesis 1 that multilateral powers ratify at a higher rate than weaker, less independent states.

To test hypotheses 2 and 3 we split our sample into treaties that the US ratified and those it did not ratify. A stratified analysis (not shown) confirmed that US ratification makes a significant difference to the behavior of other states. ${ }^{58}$ Having split the sample into two subsamples according to whether the US ratified the treaty, we estimated model 3 based on 37 treaties that the US has never ratified and model 4 based on 29 treaties that the US has ratified. The results support our expectation. When the US does not ratify, multilateral powers cooperate at a higher level both substantively and statistically (model 3). The hazard ratio of the interaction term is more than four times as large when the US does not ratify as when it does (model 4). Thus the ratification rate of the multilateral powers is

\footnotetext{
${ }^{57}$ The null model (not shown here) including only POWER and INDEPENDENCE without their interaction shows a positive effect for both variables. Although the effect of INDEPENDENCE is not significant in the null model, including both variables and their interaction improves the model considerably, and clarifies the results regarding the impact of PowER.

${ }^{58}$ This model is equivalent to model 2 except that it is stratified on the variable US RATIFICATION which identifies treaties that have been ratified by the US. In a stratified Cox proportional hazards model, separate baseline hazard functions are fitted for each strata (here: US-ratified treaties and US-not-ratified treaties). Stratification allows us to assess whether the key effect of POWER*INDEPENDENCE varies according to whether the US ratifies or not.
} 
strongly contingent on the US decision to ratify - confirming our second hypothesis that multilateral powers pick up the slack when the US does not ratify. ${ }^{59}$

The comparison between models 3 and 4 further suggests how preferences play a role for states' decisions to cooperate. When US preferences are roughly aligned with those of other states, it will take the lead in multilateral cooperation and the others can to a greater extent "free ride" by going slowly in ratification. But when US preferences differ and it is hesitant to take the lead, the other states step up in its place. ${ }^{60}$

To further assess the effect of the interaction term, we contrast the hazard ratios of multilateral powers with those of weak and/or dependent states. Here we compare a multilateral power at the $90^{t h}$ percentile of the variable values (on Power and IndePEndence), with weak and/or dependent states at the $10^{\text {th }}$ percentiles on one or both variable values. This relationship is displayed in Figure 2 for the case where the US does not ratify (model 3). Multilateral powers are the strongest supporters of multilateral treaties as indicated by the extreme peak at the back corner of the diagram (HR of 1.17). Weaker and/or dependent states represented by the three lower corners of the diagram - are hesitant supporters. Multilateral powers are between 27\% (vis-à-vis weak and dependent states; HR: 0.92 ) and $36 \%$ (vis-à-vis powerful but dependent states; HR: 0.86) more likely to ratify treaties.

\footnotetext{
${ }^{59}$ We also tested for the difference according to whether or not the US had signed a treaty. While US Signature had a significant and positive effect on others' decisions to ratify, the basic results remain unchanged. The contrast between models 3 and 4 confirms our presumption that ratification is the more significant action.

${ }^{60}$ Not all the multilateral powers need to be strongly supportive of the treaty, just enough to form an effective $k$-group to ensure ratification. Snidal 1985.
} 


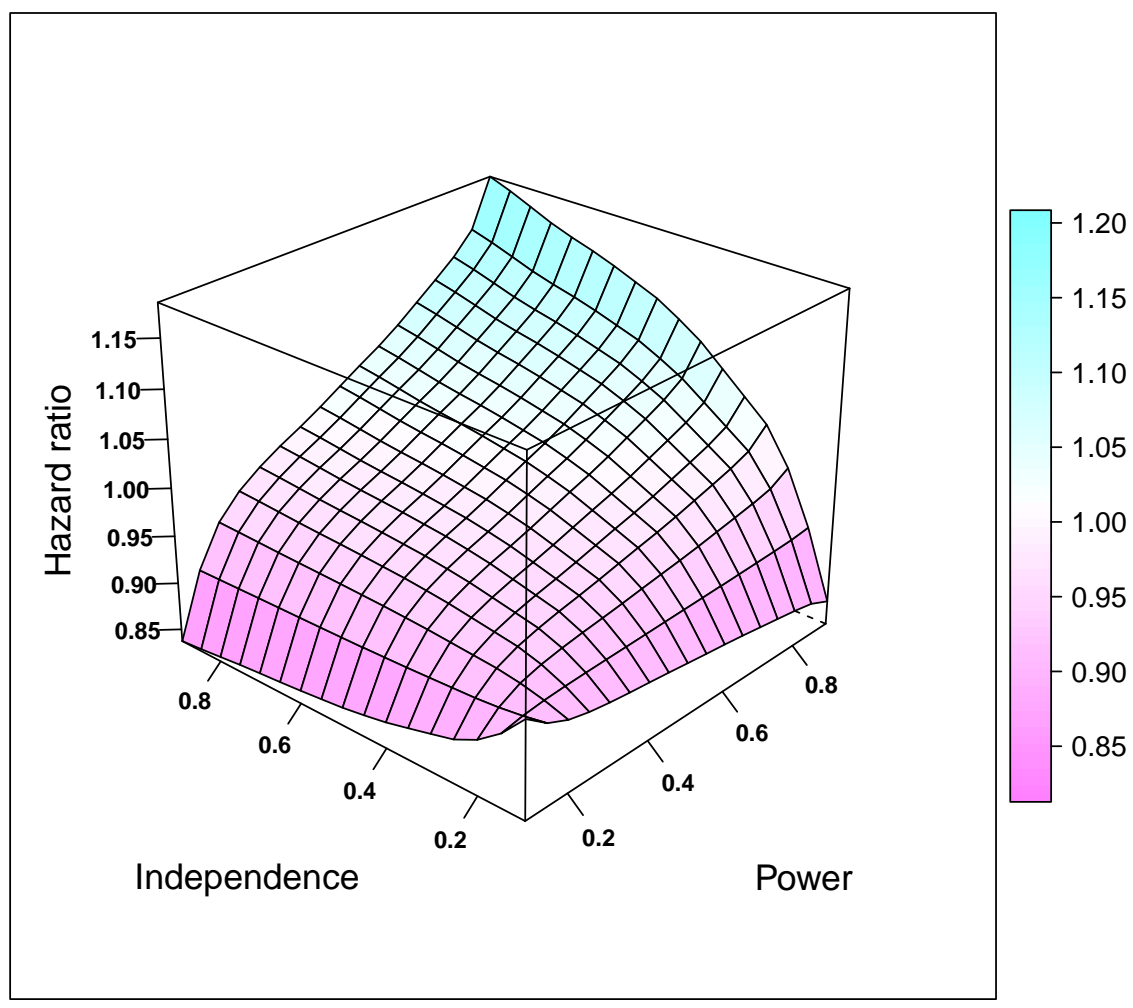

Figure 2: Visualization of the POWER*INDEPENDENCE effect from model 3.

Notes: Axes values for the two composite variables are rescaled to percentiles. The hazard ratios shown are with respect to a state with a hypothetical median position. Model 3 is based on the subsample of US non-ratified treaties.

When the US does ratify (model 4), multilateral powers remain strong supporters of international agreements (with a HR of 1.08) but the differences between multilateral powers and other states diminish considerably. This is partly because 4 multilateral powers ratify less when the US does ratify and partly because other 
${ }^{61}$ Cross-model comparisons of hazard rates based on different samples (here: treaties the US ratified in model 4 versus treaties the US did not ratify in model 3) must be made with caution. That said, such comparisons do support our hypotheses. 
In summary, our empirical findings lead to four major conclusions. First, the models reveal a robust and statistically significant effect for POWER*IndePENDENCE. The empirical pattern shows that states' support for and influence on multilateral treaties is contingent on both their might and their independence. The conjunction of power and independence, rather than simply power alone, provides the more compelling explanation of treaty ratification. Second, the analysis verifies that multilateral powers are the strongest supporters of cooperation. This is especially the case when the US hesitates or decides to stay out (suggesting that it is a preference outlier). Third, when the US does participate, it is able to pressure weak and/or dependent states to ratify - but the multilateral powers still remain the strongest supporters of multilateral cooperation. Finally, leadership in international legal cooperation requires decisiveness through speedy ratification. Overall, the results show that multilateral powers have compensated for the absence of US engagement in the post-war international system.

\section{Conclusion}

This paper has addressed the role of states' leverage in promoting international cooperation - here concretely through multilateral treaties. We have shown that multilateral powers - states that are powerful and independent of the US - are significantly more likely to ratify treaties than are other states. They are especially likely to do so - and thus provide leadership - when the US fails to ratify, or is slow to ratify. Weak and/or dependent states ratify at a much lower rate, although their rate of ratification increases when the US ratifies, supporting the conjecture that US pressure affects them.

These findings open up some interesting lines for further inquiry on international cooperation and governance more generally. First, our analysis centered on the role of multilateral powers in international legal cooperation and we have not 
investigated the role of other states in depth. More work is needed especially on what determines the decisions of "smaller" states to ratify treaties. Second, our analysis was tailored towards general patterns of legal international cooperation looking at multilateral treaties of global reach and open to universal participation, but neglects other more particular patterns. Investigating issue-specific (e.g. commodity agreements) or regional patterns (e.g. the role of regional hegemons) of cooperation would provide more detailed and complementary insights. Finally, our results are based on one specific type of cooperation. Future research should move beyond the study of international legal cooperation through treaties and assess the validity of our claims for other formalized arrangements (such as participation in international organizations), as well as for less formalized forms of cooperation (e.g., soft law agreements, G-groups). The importance of multilateral powers as drivers of cooperation also should be investigated across these alternative fora.

Our findings on how US participation affects multilateral cooperation suggest broader, though speculative, implications of shifting global power balances. Whereas the US has been commonly portrayed as indispensable for international order, other large and independent states may provide the foundation for continuing cooperation. These multilateral powers have the incentive to maintain and expand international cooperation irrespective of whether the dominant actor participates. Thus the absence of American leadership need not undermine cooperation as multilateral powers can provide direction when the US does not. This may increasingly circumscribe the ability of the US to achieve its particular goals insofar as it is not indispensable to the pursuit of multilateral cooperation.

Further questions arise with the prospective emergence of alternative leaders in international cooperation. For instance, a number of the key multilateral powers are organized through the EU which over time has become a more significant actor in treaty making, in international organizations and in international cooperation more generally. The exploration of the changing ability of the EU, not just to 
1 exercise power but also to influence smaller states, would be a useful extension 2 of our analysis. Similarly, does the growth and possibly increased coordination among the BRICS states provide another source of leadership in international cooperation?

$5 \quad$ More speculatively yet, with the continuing rise of China, will competition be6 tween the US and China dissolve into a dysfunctional rivalry or will it be channeled 7 into multilateral cooperation? If the latter, then declining power may be not dan8 gerous or destabilizing; competition for leadership when neither the US nor China 9 is singularly dominant might well have a catalytic role in promoting cooperation. 10 The declining power has incentives to participate through the treaty since it will 11 be less reliably able to control the cooperative outcome from the outside. Conversely, the rising challenger may seek to harness the power of multilateral support 13 by working inside existing arrangements rather than seeking to undermine them. ${ }_{14}$ Although the scenario of rivalry between contesting powers is not implausible, our results support the possibility that multilateral cooperation can be the prevailing solution in global governance. 


\section{References}

2 Achen, Christopher H. 2002. Toward a New Political Methodology. Microfounda$3 \quad$ tions and ART. Annual Review of Political Science 5:423-450.

4 American Non-Governmental Organizations Coalition for the International Crim5 inal Court. 2008. A Campaign for US Immunity from the ICC. Available at $6 \quad<$ http://www.amicc.org/usicc/biacampaign>. Accessed 13 April 2016.

7 Andersen, Per K., and Richard D. Gill. 1982. Cox's Regression Model for Counting

8

Processes: A Large Sample Study. Annals of Statistics 10 (4):1100-1120.

Banks, Arthur S. 2006. Cross-polity Time-series Data Archive. New York: Binghamton University.

Barbieri, Katherine. 1996. Economic Interdependence: A Path to Peace or a Source of International Conflict? Journal of Peace Research 33 (1):29-49.

Bernauer, Thomas, Anna Kalbhenn, Vally Koubi, and Gabriele Spilker. 2010. A Comparison of International and Domestic Sources of Global Governance Dynamics. British Journal of Political Science 40 (3):509-538.

Box-Steffensmeier, Janet M., and Bradford S. Jones. 2004. Event History Modeling. A Guide for Social Scientists. New York: Cambridge University Press.

Box-Steffensmeier, Janet M., and Christopher Zorn. 2002. Duration Models for Repeated Events. Journal of Politics 64 (4):1069-1094.

Brooks, Stephen G., and William C. Wohlforth. 2008. World out of Balance: International Relations and the Challenge of American Primacy. Princeton, NJ: Princeton University Press.

- 2015/16. The Rise and Fall of the Great Powers in the Twenty-first Century. International Security 40 (3):7-53. 
Byers, Michael, and Georg Nolte, eds. 2003. United States Hegemony and the Foundations of International Law. Cambridge: Cambridge University Press.

Caporaso, James A. 1992. International Relations Theory and Multilateralism: The Search for Foundations. International Organization 46 (3):599-632.

Central Intelligence Agency. 2008. The World Factbook. Washington, DC: Central Intelligence Agency.

Chayes, Antonia. 2008. How American Treaty Behavior Threatens National Security. International Security 33 (1):45-81.

Cohen, Benjamin I. 2015. Currency Power: Understanding Monetary Rivalry. Princeton, NJ: Princeton University Press.

Correlates Of War Project. 2003. Composition of MID 3 Regions Version: 02/05/2003. Available at <http://cow. la.psu.edu/COW2\%20Data/MIDs / Development/regions.htm>. Accessed 13 April 2016.

Correlates of War Project. 2005. National Material Capabilities, Version 3.02. Available at <http://www. correlatesofwar.org/>. Accessed 13 April 2016.

- 2008. State System Membership List, Version 2008.1. Available at <http: //www. correlatesofwar.org/>. Accessed 13 April 2016.

Downs, George W., David M. Rocke, and Peter N. Barsoom. 1996. Is the Good News about Compliance Good News about Cooperation? International Organization 50 (3):379-406.

Finnemore, Martha. 1996. National Interests in International Society. Ithaca, NY: Cornell University Press.

Finnemore, Martha, and Kathryn Sikkink. 1998. International Norm Dynamics and Political Change. International Organization 52 (4):887-917. 
Gilbert, Paul D., and Erik Meijer. 2005. Time Series Factor Analysis with an Application to Measuring Money. Research Report No. 05F10. SOM Research School, University of Groningens. Available at <http://som.eldoc.ub.rug. nl/reports/themeF/2005/05F10/>. Accessed 13 April 2016.

Gilpin, Robert. 2011. Global Political Economy. Princeton, NJ: Princeton University Press.

Gleditsch, Kristian S. 2006. Expanded Trade and GDP Data. Available at <http://privatewww.essex.ac.uk/ ksg/exptradegdp.html>. Accessed 13 April 2016.

Goodliffe, Jay, and Darren G. Hawkins. 2006. Explaining Commitment: States and the Convention against Torture. Journal of Politics 68 (2):358-371.

Haftel, Yoram Z., and Alexander Thompson. 2013. Delayed Ratification: The Domestic Fate of Bilateral Investment Treaties. International Organization $67(2): 355-387$.

Hathaway, Oona A. 2008. Treaties' End: The Past, Present, and Future of International Lawmaking in the United States. Yale Law Journal 117 (7):1236-1372.

Heston, Alan, Robert Summers, and Bettina Aten. 2006. Penn World Table Version 6.2. Philadelphia, PA: Center for International Comparisons of Production, Income and Prices, University of Pennsylvania.

Hirschman, Albert O. 1945. National Power and the Structure of Foreign Trade. Berkeley and Los Angeles, CA: University of California Press.

Ikenberry, G. John. 2000. After Victory. Institutions, Strategic Restraint, and the Rebuilding of Order after Major Wars. Princeton, NJ: Princeton University Press. 
Ikenberry, G. John, and Charles A. Kupchan. 1990. Socialization and Hegemonic Power. International Organization 44 (3):283-315.

Institute for Agriculture and Trade Policy. 2005. The Treaty Database. U.S. Compliance with Global Treaties. Available at <http://www.iatp.org/files/451_ 2_60426.pdf>. Accessed 13 April 2016.

Kagan, Robert. 2003. Paradise and Power: America and Europe in the New World Order. New York: Knopf.

Kahler, Miles. 1992. Multilateralism with Small and Large Numbers. International Organization 46 (3):681-708.

Kaul, Inge, Pedro Conceição, Katell Le Goulven, and Ronald U. Mendoza, eds. 2003. Providing Global Public Goods: Managing Globalization. Oxford: Oxford University Press.

Kelley, Judith. 2007. Who Keeps International Commitments and Why? The International Criminal Court and Bilateral Nonsurrender Agreements. American Political Science Review 101 (3):573-589.

Kelley, Judith G., and Jon C.W. Pevehouse. Forthcoming. An Opportunity Cost Theory of US Treaty Behavior. International Studies Quarterly.

Keohane, Robert O. 1984. After Hegemony: Cooperation and Discord in the World Political Economy. Princeton, NJ: Princeton University Press.

Keohane, Robert O., and Joseph S. Nye. 1977. Power and Interdependence: World Politics in Transition. Boston, MA: Little, Brown.

Kindleberger, Charles. 1973. The World in Depression, 1929-1939. Berkeley, CA: University of California Press. 
Kirshner, Jonathan. 2003. States, Markets, and Great Power Relations in the Pacific: Some Realist Expectations. In International Relations Theory and the Asia Pacific, edited by John G. Ikenberry and Michael Mastanduno, 273-298. New York: Columbia University Press.

Klein, John P., and Melvin L. Moeschberger. 2003. Survival Analysis. Techniques for Censored and Truncated Data. New York: Springer Verlag.

La Porta, Rafael, Florencio López-de Silanes, Andrei Shleifer, and Robert W. Vishny. 1999. The Quality of Government. Journal of Law, Economics and Organization 15 (1):222-279.

Lönnroth, Juhani. 1991. The International Convention on the Rights of All Migrant Workers and Members of Their Families in the Context of International Migration Policies: An Analysis of Ten Years of Negotiation. International Migration Review 25 (4):710-736.

Lupu, Yonatan. Forthcoming. Why Do States Join Some Universal Treaties but Not Others? An Analysis of Treaty Commitment Preferences. Journal of Conflict Resolution.

Marshall, Monty G., and Keith Jaggers. 2007. Polity IV Project. Political Regime Characteristics, and Transitions. Available at <http://www. systemicpeace. org/polity/polity4.htm>. Accessed 13 April 2016.

Martin, Lisa L. 1992. Interests, Power, and Multilateralism. International Organization 46 (4):765-792.

Milewicz, Karolina, and Manfred Elsig. 2014. The Hidden World of Multilateralism? Treaty Commitments of Newly Democratized States in Europe. International Studies Quarterly 58 (2):322-335. 
1 Monteiro, Nuno P. 2014. Theory of Unipolar Politics. New York: Cambridge University Press.

3 Moravcsik, Andrew. 2000. The Origins of Human Rights Regimes: Democratic

$4 \quad$ Delegation in Postwar Europe. International Organization 54 (2):217-252.

5 Neumayer, Eric. 2002. Do Democracies Exhibit Stronger International Environ6 mental Commitment? A Cross-country Analysis. Journal of Peace Research $7 \quad 39(2): 139-164$.

Norrlof, Carla. 2010. America's Global Advantage: US Hegemony and International Cooperation. Cambridge: Cambridge University Press.

Pollack, Mark A. 2015. Who Supports International Law, and Why?: The United States, the European Union, and the International Legal Order. International Journal of Constitutional Law 13 (4):873-900.

R Development Core Team. 2014. R: A Language and Environment for Statistical Computing. The R Foundation for Statistical Computing, Vienna, Austria. Available at <http://www.r-project.org>. Accessed 13 April 2016.

Rubenfeld, Jed. 2004. Commentary: Unilateralism and Constitutionalism. New York University Law Review 79 (6):1971-2028.

Ruggie, John Gerard. 1992. Multilateralism: The Anatomy of an Institution. International Organization 46 (3):561-598.

Schelling, Thomas C. 1978. Micromotives and Macrobehavior. New York: Norton. Scott, Shirley V. 2004. International Law in World Politics: An Introduction. London: Lynne Rienner Publishers.

- 2012. International Law, US Power: The United States' Quest for Legal Security. Cambridge: Cambridge University Press. 
1 Simmons, Beth A. 2000. The Legalization of International Monetary Affairs. In$2 \quad$ ternational Organization 54 (3):573-602.

3

4

- 2009. Mobilizing for Human Rights. International Law in Domestic Politics. New York: Cambridge University Press.

Snidal, Duncan. 1985. The Limits of Hegemonic Stability Theory. International Organization 39 (4):579-614.

Steinberg, Richard H. 2002. In the Shadow of Law or Power? Consensus-based Bargaining and Outcomes in the GATT/WTO. International Organization $56(2): 339-374$.

Stone, Randall W. 2011. Controlling Institutions: International Organizations and the Global Economy. Cambridge: Cambridge University Press.

Tableman, Mara, and Jong Sung Kim. 2004. Survival Analysis Using S. Analysis of Time-to-Event Data. London: Chapman \& Hall.

Teorell, Jan, and Axel Hadenius. 2005. Assessing Alternative Indices of Democracy. Political Concepts Working Paper 6. The Committee on Concepts and Methods, International Political Science Association. Available at <http://www. concepts-methods.org/Files/WorkingPaper/PC\%206\% 20Hadenius\%20Teorell.pdf>. Accessed 13 April 2016.

Therneau, Terry M. 2015. Survival: Survival analysis. R package version 2.38-3. Available at <http://CRAN.R-project.org/package=survival>. Accessed 13 April 2016.

Therneau, Terry M., and Patricia M. Grambsch. 2000. Modeling Survival Data: Extending the Cox Model. New York: Springer Verlag.

Vienna Convention on the Law of Treaties. 1969. United Nations, Treaty 
1 Series 1155: 331-512. Available at <https://treaties.un.org/pages/

$2 \quad$ showDetails.aspx?objid=080000028003902f>. Accessed 10 February 2016.

von Stein, Jana. 2008. The International Law and Politics of Climate Change. Rat-

$4 \quad$ ification of the United Nations Framework Convention and the Kyoto Protocol.

$5 \quad$ Journal of Conflict Resolution 52 (2):243-268.

6 Vreeland, James R. 2003. Why Do Governments and the IMF Enter into Agree$7 \quad$ ments? Statistically Selected Cases. International Political Science Review $8 \quad 24(3): 321-343$.

9 2008. Political Institutions and Human Rights: Why Dictatorships Enter

10 Into the United Nations Convention Against Torture. International Organization $11 \quad 62(1): 65-101$.

12 Wood, Simon N. 2006. Generalized Additive Models: An Introduction with $R$. London: Chapman \& Hall/CRC Press.

14 World Bank. 2007. World Development Indicators (WDI) 200\%. Washington, DC: 15 World Bank. 


\section{- A Treaty sample and data}

\begin{tabular}{|c|c|c|c|c|c|c|}
\hline & abbreviation & adopted & in force & treaty & US ratified & IATP sample \\
\hline 1 & CUN & 1945 & 1945 & Charter of the United Nations & 1945 & - \\
\hline 2 & CPPCG & 1948 & 1951 & Convention on the Prevention and Punishment of the Crime of Genocide & 1988 & - \\
\hline 3 & $\mathrm{C} 87$ & 1948 & 1950 & $\begin{array}{l}\text { C87 Freedom of Association and Protection of the Right to Organise } \\
\text { Convention }\end{array}$ & - & $\mathrm{X}$ \\
\hline 4 & $\mathrm{GC}$ & 1949 & 1950 & Geneva Conventions & 1955 & $\mathrm{X}$ \\
\hline 5 & C98 & 1949 & 1951 & C98 Right to Organise and Collective Bargaining Convention & - & $\mathrm{X}$ \\
\hline 6 & $\mathrm{C} 100$ & 1951 & 1953 & C100 Equal Remuneration Convention & - & $\mathrm{X}$ \\
\hline 7 & $\mathrm{C} 105$ & 1957 & 1959 & C105 Abolition of Forced Labour Convention & 1991 & $\mathrm{X}$ \\
\hline 8 & C111 & 1958 & 1960 & C111 Discrimination (Employment and Occupation) Convention & - & $\mathrm{X}$ \\
\hline 9 & VCDR & 1961 & 1964 & Vienna Convention on Diplomatic Relations & 1972 & - \\
\hline 10 & PTBT & 1963 & 1963 & $\begin{array}{l}\text { Treaty Banning Nuclear Weapon Tests in the Atmosphere, in Outer Space } \\
\text { and under Water }\end{array}$ & 1963 & - \\
\hline 11 & CERD & 1965 & 1969 & $\begin{array}{l}\text { International Convention on the Elimination of All Forms of Racial Dis- } \\
\text { crimination }\end{array}$ & 1994 & $\mathrm{X}$ \\
\hline 12 & ICCPR & 1966 & 1976 & International Covenant on Civil and Political Rights & 1992 & $\mathrm{X}$ \\
\hline 13 & ICESCR & 1966 & 1976 & International Covenant on Economic, Social and Cultural Rights & - & $\mathrm{X}$ \\
\hline 14 & OPICCPR & 1966 & 1976 & $\begin{array}{l}\text { Optional Protocol to the International Covenant on Civil and Political } \\
\text { Rights }\end{array}$ & - & $\mathrm{X}$ \\
\hline 15 & NPT & 1968 & 1970 & Treaty on the Non-Proliferation of Nuclear Weapons & 1970 & $\mathrm{X}$ \\
\hline 16 & VCLT & 1969 & 1980 & Vienna Convention on the Law of Treaties & - & $\mathrm{X}$ \\
\hline
\end{tabular}

Table 3: Sample of 66 multilateral treaties. 


\begin{tabular}{|c|c|c|c|c|c|c|}
\hline & abbreviation & adopted & in force & treaty & US ratified & IATP sample \\
\hline 17 & $\mathrm{BWC}$ & 1972 & 1975 & $\begin{array}{l}\text { Convention on the Prohibition of the Development, Production and } \\
\text { Stockpiling of Bacteriological (Biological) and Toxin Weapons and on } \\
\text { Their Destruction }\end{array}$ & 1975 & $\mathrm{X}$ \\
\hline 18 & CITES & 1973 & 1975 & $\begin{array}{l}\text { Convention on International Trade in Endangered Species of Wild Fauna } \\
\text { and Flora }\end{array}$ & 1974 & - \\
\hline 19 & C138 & 1973 & 1976 & C138 Minimum Age Convention & - & $\mathrm{X}$ \\
\hline 20 & APGC & 1977 & 1978 & $\begin{array}{l}\text { Protocol Additional to the Geneva Conventions of } 12 \text { August 1949, and } \\
\text { Relating to the Protection of Victims of International Armed Conflicts } \\
\text { (Protocol I) }\end{array}$ & - & $\mathrm{X}$ \\
\hline 21 & APIIGC & 1977 & 1978 & $\begin{array}{l}\text { Protocol Additional to the Geneva Conventions of } 12 \text { August } 1949 \text { and } \\
\text { Relating to the Protection of Victims of Non-International Armed Con- } \\
\text { flicts (Protocol II) }\end{array}$ & - & $\mathrm{X}$ \\
\hline 22 & CEDAW & 1979 & 1981 & $\begin{array}{l}\text { Convention on the Elimination of All Forms of Discrimination against } \\
\text { Women }\end{array}$ & - & $\mathrm{X}$ \\
\hline 23 & CMS & 1979 & 1983 & Convention on the Conservation of Migratory Species of Wild Animals & - & - \\
\hline 24 & CCWCPIPIII & 1980 & 1983 & $\begin{array}{l}\text { Convention on Prohibitions or Restrictions on the Use of Certain Con- } \\
\text { ventional Weapons which may be deemed to be Excessively Injurious or } \\
\text { to have Indiscriminate Effects (with Protocols I, II and III)- with Pro- } \\
\text { tocol on Prohibitions or Restrictions on the Use of Mines, Booby-Traps } \\
\text { and Other Devices as amended on } 3 \text { May } 1996 \text { (Protocol II as amended } \\
\text { on } 3 \text { May 1996) }\end{array}$ & 1995 & - \\
\hline 25 & UNCLS & 1982 & 1994 & United Nations Convention on the Law of the Sea & - & $\mathrm{X}$ \\
\hline 26 & $\mathrm{CAT}$ & 1984 & 1987 & $\begin{array}{l}\text { Convention against Torture and Other Cruel, Inhuman or Degrading } \\
\text { Treatment or Punishment }\end{array}$ & 1994 & $\mathrm{X}$ \\
\hline 27 & VCPOL & 1985 & 1988 & Vienna Convention for the Protection of the Ozone Layer & 1986 & - \\
\hline 28 & VCIO & 1986 & & $\begin{array}{l}\text { Vienna Convention on the Law of Treaties between States and Interna- } \\
\text { tional Organizations or between International Organizations }\end{array}$ & - & - \\
\hline 29 & MP & 1987 & 1989 & Montreal Protocol on Substances that Deplete the Ozone Layer & 1988 & $\mathrm{X}$ \\
\hline
\end{tabular}

Table 3. Sample of 66 multilateral treaties. 


\begin{tabular}{|c|c|c|c|c|c|c|}
\hline & abbreviation & adopted & in force & treaty & US ratified & IATP sample \\
\hline 30 & OPIIICCPR & 1989 & 1991 & $\begin{array}{l}\text { Second Optional Protocol to the International Covenant on Civil and } \\
\text { Political Rights, aiming at the Abolition of the Death Penalty }\end{array}$ & - & $\mathrm{X}$ \\
\hline 31 & $\mathrm{CRC}$ & 1989 & 1990 & Convention on the Rights of the Child & - & $\mathrm{X}$ \\
\hline 32 & $\mathrm{BC}$ & 1989 & 1992 & $\begin{array}{l}\text { Basel Convention on the Control of Transboundary Movements of Haz- } \\
\text { ardous Wastes and their Disposal }\end{array}$ & - & $\mathrm{X}$ \\
\hline 33 & ICRMW & 1990 & 2003 & $\begin{array}{l}\text { International Convention on the Protection of the Rights of All Migrant } \\
\text { Workers and Members of their Families }\end{array}$ & - & $\mathrm{X}$ \\
\hline 34 & UNFCCC & 1992 & 1994 & United Nations Framework Convention on Climate Change & 1992 & $\mathrm{X}$ \\
\hline 35 & CWC & 1992 & 1997 & $\begin{array}{l}\text { Convention on the Prohibition of the Development, Production, Stock- } \\
\text { piling and Use of Chemical Weapons and on their Destruction }\end{array}$ & 1997 & $\mathrm{X}$ \\
\hline 36 & CBD & 1992 & 1993 & Convention on Biological Diversity & - & $\mathrm{X}$ \\
\hline 37 & UNCCD & 1994 & 1996 & United Nations Convention to Combat Desertification & 2000 & $\mathrm{X}$ \\
\hline 38 & PIVCCWC & 1995 & 1998 & $\begin{array}{l}\text { Additional Protocol to the Convention on Prohibitions or Restrictions } \\
\text { on the Use of Certain Conventional Weapons which may be deemed to } \\
\text { be Excessively Injurious or to have Indiscriminate Effects (Protocol IV, } \\
\text { entitled Protocol on Blinding Laser Weapons) }\end{array}$ & 2009 & - \\
\hline 39 & CTBT & 1996 & & Comprehensive Nuclear-Test-Ban Treaty & - & $\mathrm{X}$ \\
\hline 40 & $\mathrm{TBC}$ & 1997 & 2001 & International Convention for the Suppression of Terrorist Bombings & 2002 & - \\
\hline 41 & KPCC & 1997 & 2005 & $\begin{array}{l}\text { Kyoto Protocol to the United Nations Framework Convention on Climate } \\
\text { Change }\end{array}$ & 一 & $\mathrm{X}$ \\
\hline 42 & APMC & 1997 & 1999 & $\begin{array}{l}\text { Convention on the Prohibition of the Use, Stockpiling, Production and } \\
\text { Transfer of Anti-Personnel Mines and on their destruction }\end{array}$ & - & $\mathrm{X}$ \\
\hline 43 & $\mathrm{RC}$ & 1998 & 2004 & $\begin{array}{l}\text { Rotterdam Convention on the Prior Informed Consent Procedure for Cer- } \\
\text { tain Hazardous Chemicals and Pesticides in International Trade }\end{array}$ & - & $\mathrm{X}$ \\
\hline 44 & RSICC & 1998 & 2002 & Rome Statute of the International Criminal Court & - & $\mathrm{X}$ \\
\hline
\end{tabular}

Table 3. Sample of 66 multilateral treaties. 


\begin{tabular}{|c|c|c|c|c|c|c|}
\hline & abbreviation & adopted & in force & treaty & US ratified & IATP sample \\
\hline 45 & C182 & 1999 & 2000 & C182 Worst Forms of Child Labour Convention & 1999 & $\mathrm{X}$ \\
\hline 46 & TFC & 1999 & 2002 & $\begin{array}{l}\text { International Convention for the Suppression of the Financing of Terror- } \\
\text { ism }\end{array}$ & 2002 & $\mathrm{X}$ \\
\hline 47 & OPCEDAW & 1999 & 2000 & $\begin{array}{l}\text { Optional Protocol to the Convention on the Elimination of All Forms of } \\
\text { Discrimination against Women }\end{array}$ & - & $\mathrm{X}$ \\
\hline 48 & $\mathrm{PBC}$ & 1999 & & $\begin{array}{l}\text { Basel Protocol on Liability and Compensation for Damage Resulting from } \\
\text { Transboundary Movements of Hazardous Wastes and their Disposal }\end{array}$ & - & - \\
\hline 49 & OPCRC & 2000 & 2002 & $\begin{array}{l}\text { Optional Protocol to the Convention on the Rights of the Child on the } \\
\text { Involvement of Children in Armed Conflict }\end{array}$ & 2002 & $\mathrm{X}$ \\
\hline 50 & OPIICRC & 2000 & 2002 & $\begin{array}{l}\text { Optional Protocol to the Convention on the Rights of the Child on the } \\
\text { Sale of Children, Child Prostitution and Child Pornography }\end{array}$ & 2002 & $\mathrm{X}$ \\
\hline 51 & UNCTOC & 2000 & 2003 & United Nations Convention against Transnational Organized Crime & 2005 & - \\
\hline 52 & PIUNCTOC & 2000 & 2003 & $\begin{array}{l}\text { Protocol to Prevent, Suppress and Punish Trafficking in Persons, Espe- } \\
\text { cially Women and Children, supplementing the United Nations Conven- } \\
\text { tion against Transnational Organized Crime }\end{array}$ & 2005 & - \\
\hline 53 & PIIUNCTOC & 2000 & 2004 & $\begin{array}{l}\text { Protocol against the Smuggling of Migrants by Land, Sea and Air, supple- } \\
\text { menting the United Nations Convention against Transnational Organized } \\
\text { Crime }\end{array}$ & 2005 & - \\
\hline 54 & CPCBD & 2000 & 2003 & $\begin{array}{l}\text { Cartagena Protocol on Biosafety to the Convention on Biological Diver- } \\
\text { sity }\end{array}$ & - & $\mathrm{X}$ \\
\hline 55 & $\mathrm{SC}$ & 2001 & 2004 & Stockholm Convention on Persistent Organic Pollutants & - & $\mathrm{X}$ \\
\hline 56 & PGRT & 2001 & 2004 & International Treaty on Plant Genetic Resources for Food and Agriculture & - & $\mathrm{X}$ \\
\hline 57 & PIIIUNCTOC & 2001 & 2005 & $\begin{array}{l}\text { Protocol against the Illicit Manufacturing of and Trafficking in Firearms, } \\
\text { Their Parts and Components and Ammunition, supplementing the } \\
\text { United Nations Convention against Transnational Organized Crime }\end{array}$ & - & - \\
\hline
\end{tabular}

Table 3. Sample of 66 multilateral treaties. 


\begin{tabular}{|c|c|c|c|c|c|c|}
\hline & abbreviation & adopted & in force & treaty & US ratified & IATP sample \\
\hline 58 & OPCAT & 2002 & 2006 & $\begin{array}{l}\text { Optional Protocol to the Convention against Torture and Other Cruel, } \\
\text { Inhuman or Degrading Treatment or Punishment }\end{array}$ & - & - \\
\hline 59 & UNCC & 2003 & 2005 & United Nations Convention against Corruption & 2006 & - \\
\hline 60 & PVCCWC & 2003 & 2006 & $\begin{array}{l}\text { Protocol on Explosive Remnants of War to the Convention on Prohibi- } \\
\text { tions or Restrictions on the Use of Certain Conventional Weapons which } \\
\text { may be deemed to be Excessively Injurious or to have Indiscriminate } \\
\text { Effects (Protocol V) }\end{array}$ & 2009 & - \\
\hline 61 & NTC & 2005 & 2007 & $\begin{array}{l}\text { International Convention for the Suppression of Acts of Nuclear Terror- } \\
\text { ism }\end{array}$ & - & - \\
\hline 62 & CRPD & 2006 & 2008 & Convention on the Rights of Persons with Disabilities & - & - \\
\hline 63 & OPCRPD & 2006 & 2008 & $\begin{array}{l}\text { Optional Protocol to the Convention on the Rights of Persons with Dis- } \\
\text { abilities }\end{array}$ & - & - \\
\hline 64 & CAED & 2006 & 2010 & $\begin{array}{l}\text { International Convention for the Protection of All Persons from Enforced } \\
\text { Disappearance }\end{array}$ & - & - \\
\hline 65 & OPICESCR & 2008 & & $\begin{array}{l}\text { Optional Protocol to the International Covenant on Economic, Social and } \\
\text { Cultural Rights }\end{array}$ & - & - \\
\hline 66 & $\mathrm{CCM}$ & 2008 & 2010 & Convention on Cluster Munitions & - & - \\
\hline
\end{tabular}

Table 3. Sample of 66 multilateral treaties. 


\begin{tabular}{|c|c|c|}
\hline Variable & Definition & Source \\
\hline military expenditure & Total military budget in thousands of current year US\$. & $\begin{array}{l}\text { Correlates of War } \\
\text { Project } 2005 .\end{array}$ \\
\hline military personnel & $\begin{array}{l}\text { Troops under the command of the national government (in thousands) ready for combat as of January } 1 \\
\text { of the referent year. }\end{array}$ & $\begin{array}{l}\text { Correlates of War } \\
\text { Project } 2005 .\end{array}$ \\
\hline energy consumption & $\begin{array}{l}\text { Primary energy consumption measured as the industrial capacity; sum of four categories of sources - coal, } \\
\text { petroleum, electricity, and natural gas, converted into thousands of coal-ton equivalents. }\end{array}$ & $\begin{array}{l}\text { Correlates of War } \\
\text { Project } 2005 .\end{array}$ \\
\hline total trade & Sum of imports and exports in millions of current year US\$. & Gleditsch 2006. \\
\hline \multirow[t]{4}{*}{ GDP per capita (log) } & real GDP per capita - Chain index in constant $1996 \mathrm{US} \$$. & $\begin{array}{l}\text { Heston, Summers, } \\
\text { and Aten } 2006 .\end{array}$ \\
\hline & growth rate of GDP per capita - Annual percentage, based on constant local currency. & World Bank 2007. \\
\hline & GDP per capita - GDP in constant 2000 US\$ divided by midyear population. & World Bank 2007. \\
\hline & gdp deflator - Ratio of GDP in current local currency to GDP in constant local currency. & World Bank 2007. \\
\hline $\begin{array}{l}\text { government } \\
\text { expenditure }\end{array}$ & $\begin{array}{l}\text { General government final consumption expenditure in current US } \$ \text { including all government current expen- } \\
\text { ditures for purchases of goods and services (compensation of employees, expenditures on national defense } \\
\text { and security), and excluding government military expenditures that are part of government capital forma- } \\
\text { tion. }\end{array}$ & $\begin{array}{l}\text { World Bank 2007; } \\
\text { and Banks } 2006 .\end{array}$ \\
\hline literacy rate & $\begin{array}{l}\text { Percentage of people aged } 15 \text { years and above who can read and write a short, simple statement on their } \\
\text { everyday life. }\end{array}$ & $\begin{array}{l}\text { World Bank 2007; } \\
\text { and Banks } 2006 .\end{array}$ \\
\hline physicians & $\begin{array}{l}\text { Graduates of any facility or school of medicine who are working in the country in any medical field (practice, } \\
\text { teaching, research) per 1,000 people. }\end{array}$ & $\begin{array}{l}\text { World Bank 2007; } \\
\text { and Banks } 2006 .\end{array}$ \\
\hline total population (log) & $\begin{array}{l}\text { All residents regardless of legal status or citizenship - except for refugees not permanently settled in the } \\
\text { country of asylum, who are generally considered part of the population of a state of origin. }\end{array}$ & $\begin{array}{l}\text { Heston, Summers, } \\
\text { and Aten 2006; and } \\
\text { World Bank } 2007 .\end{array}$ \\
\hline adult population & Percentage of the total population in the age group 15 to 64 . & World Bank 2007. \\
\hline
\end{tabular}

Table 4: Constituent variables of the Power index. 


\begin{tabular}{lccccc}
\hline & Min & Max & Mean & Std. Deviation & Observations \\
\hline POWER & 0.12 & 2.8 & 1.39 & 0.13 & 94604 \\
GDP & 2.178 & 15.49 & 8.65 & 2.43 & 103374 \\
INDEPENDENCE & 0.12 & 1 & 0.88 & 0.14 & 81502 \\
DEPENDENCE & 0 & 4.7 & 0.09 & 0.23 & 65927 \\
\hline Controls & & & & & \\
DEMOCRACY & -10 & 10 & -0.27 & 7.20 & 94191 \\
NEW DEMOCRACY & 0 & 1 & 0.11 & 0.31 & 99332 \\
STATE AGE & 0 & 63 & 29.33 & 17.25 & 126701 \\
EUROPE & 0 & 1 & 0.10 & 0.30 & 126701 \\
ISSUE AREA & 1 & 4 & 2.48 & 0.89 & 126701 \\
COLONIAL PAST & 0 & 1 & 0.7 & 0.46 & 122981 \\
RELIGION (MUSLIM) & 0 & 1 & 0.24 & 0.43 & 121661 \\
RRIS & 0 & 0.5 & 0.06 & 0.03 & 126651 \\
SignatURE & 0 & 1 & 0.23 & 0.42 & 126701 \\
\hline
\end{tabular}

Table 5: Descriptive statistics. 


\begin{tabular}{|c|c|}
\hline Variable & Definition \\
\hline POWER & $\begin{array}{l}\text { Power indicator transformed to state power position relative } \\
\text { to the US; (original measure standardized around " } 0 \text { " with } \\
\text { max. value at "1"); higher values indicate greater capabilities. }\end{array}$ \\
\hline GDP & $\begin{array}{l}\text { Log of GDP in current US dollars (millions). World Bank } \\
2007 .\end{array}$ \\
\hline \multirow[t]{4}{*}{ INDEPENDENCE } & $\begin{array}{l}\text { Independence from the dominant actor, measured as trade } \\
\text { independence of a given state from the US in terms of } \\
\text { the balance of trade shares: trade independence }{ }_{i, U S}=1- \\
\left(\text { trade share }_{i, U S}-\text { trade share }_{U S, i} \text {. }\right.\end{array}$ \\
\hline & $\begin{array}{l}\text { Trade share for a given } \text { state }_{i} \text { is defined as } \\
\text { trade share } \text { imports }_{i, U S}=\frac{\text { imports }_{i, U S}}{\text { imports }_{i}+\operatorname{exports}_{i}}=\frac{\text { trade }_{i, U S}}{\text { trade }_{i}} \\
\text { and for the US as }\end{array}$ \\
\hline & $\operatorname{trade~share~}_{U S, i}=\frac{\text { imports }_{U S, i}+\operatorname{exports}_{U S, i}}{\text { imports }_{U S}+\operatorname{exports}_{U S}}=\frac{\operatorname{trade}_{U S, i}}{\operatorname{trde}_{U S}}$ \\
\hline & $\begin{array}{l}\text { higher values indicate greater trade independence; based on } \\
\text { Gleditsch } 2006 \text {. }\end{array}$ \\
\hline DEPENDENCE & $\begin{array}{l}\text { Trade dependence of a given state measured as a state's trade } \\
\text { with the US as a proportion of the state's GDP; higher values } \\
\text { indicate greater dependence and lower independence; based } \\
\text { on Gleditsch } 2006 \text { and World Bank } 2007 \text {. }\end{array}$ \\
\hline DEMOCRACY & $\begin{array}{l}\text { (Revised Combined) polity2 score (Polity IV Index); higher } \\
\text { values indicate more democracy. Marshall and Jaggers } 2007 .\end{array}$ \\
\hline NeW Democracy & $\begin{array}{l}\text { Binary time-invariant measure for whether a state is a "new } \\
\text { democracy" or not; based on Marshall and Jaggers } 2007 \text {; } \\
\text { states with averaged polity values of less than } 1 \text { in the pe- } \\
\text { riod } 1970-1988 \text {, and values greater than or equal to } 5 \text { post } \\
1999 \text { are coded as new democracies. Milewicz and Elsig } 2014 \text {. }\end{array}$ \\
\hline State Age & $\begin{array}{l}\text { Years of existence post-1945, based on state sovereignty or } \\
\text { state formation; based on Central Intelligence Agency } 2008 \text {, } \\
\text { and cross-checked with the Correlates of War Project } 2008 \text {. }\end{array}$ \\
\hline Europe & $\begin{array}{l}\text { Binary time-invariant measure coding whether a state is lo- } \\
\text { cated in Western Europe; based on Teorell and Hadenius } \\
2005 \text {. }\end{array}$ \\
\hline HUMAN \& LABOR & Issue area of the treaty coded as a time-invariant categorical \\
\hline $\begin{array}{l}\text { RightS, SECURITY, } \\
\text { ENVIRONMENT }\end{array}$ & variable with RULE OF LAW as reference category. \\
\hline COLONial Past & $\begin{array}{l}\text { Binary time-invariant variable measuring whether a state has } \\
\text { been colonized since } 1700 \text {; based on Teorell and Hadenius } \\
2005 \text {. }\end{array}$ \\
\hline $\begin{array}{l}\text { RELIGION (MUS- } \\
\text { LIM) }\end{array}$ & $\begin{array}{l}\text { Binary time-invariant variable measuring whether the major- } \\
\text { ity of a state's population is of Muslim or other denomination; } \\
\text { based on La Porta, López-de Silanes, Shleifer et al. } 1999 .\end{array}$ \\
\hline RRIS & $\begin{array}{l}\text { Regional Ratification Intensity Score giving the ratio of actual } \\
\text { ratifications to possible ratifications for all states in a given } \\
\text { year and a given region; based on Correlates Of War Project } \\
2003 \text {; lagged by one year; higher values indicate higher ratifi- } \\
\text { cation intensity. }\end{array}$ \\
\hline Signature & Binary variable measuring whether a state has signed a treaty. \\
\hline
\end{tabular}

Table 6: Explanatory variables. 


\section{B Robustness checks}

To assess the robustness and general validity of our results, we conducted additional tests. First, we double-checked our results on a simpler data structure that accounts only for the presence of right-censored data but not for left-truncated observations. This modification allows for time to ratification to vary across countries, but does not take account of the historical sequence of treaties. While it is less appropriate for our data, it is a standard approach. The results based on the data structure adjusted only for right-censoring lead to almost identical results. In particular, the effect for the interaction terms is similar to those presented. The coefficient estimates are likewise robust and statistically significant.

Second, to rule out the possibility that other factors might drive the results, we conducted additional tests for alternative explanations. We examined the effect of COLONIAL $\mathrm{PAST}^{62}$ on support for ratification because of the persistence of the former colonial legal order. Since states with Western/secular values might be more inclined to participate in treaty making, we tested for whether the majority of a state's population is Muslim ${ }^{63}$ expecting a negative link between RELIGION (MusLim) and the likelihood of ratification. We also controlled for the geographic diffusion of international norms ${ }^{64}$ using a regional ratification intensity score (RRIS). We expected states sharing the same geographic region to display similar ratification patterns. Finally, as a state's ratification can be positively contingent upon its previous treaty-related actions, we controlled in our models for SignATURE expecting positive relationship. While these alternative controls had the expected effect or no effect, their inclusion did not greatly affect the interaction term. Results based on the subsample of US non-ratified treaties are presented in Table 7 .

\footnotetext{
${ }^{62}$ Teorell and Hadenius 2005.

${ }^{63}$ La Porta, López-de Silanes, Shleifer et al. 1999.

${ }^{64}$ Finnemore 1996.
} 


\begin{tabular}{|c|c|c|c|}
\hline & $\begin{array}{l}\text { Model A1 } \\
\exp (\text { coef }) \\
(p)\end{array}$ & $\begin{array}{l}\text { Model A2 } \\
\exp (\text { coef }) \\
(p)\end{array}$ & $\begin{array}{l}\text { Model A3 } \\
\exp (\text { coef }) \\
(p)\end{array}$ \\
\hline POWER & $\begin{array}{l}0.05 \\
\left(0.004^{* *}\right)\end{array}$ & $\begin{array}{l}0.1 \\
\left(0.024^{*}\right)\end{array}$ & $\begin{array}{l}0.12 \\
(0.05 \cdot)\end{array}$ \\
\hline INDEPENDENCE & $\begin{array}{l}0.01 \\
\left(0.003^{* *}\right)\end{array}$ & $\begin{array}{l}0.01 \\
\left(0.009^{* *}\right)\end{array}$ & $\begin{array}{l}0.02 \\
\left(0.02^{*}\right)\end{array}$ \\
\hline Power*INDEPEndEnCE & $\begin{array}{l}47.26 \\
\left(0.001^{* *}\right)\end{array}$ & $\begin{array}{l}25.06 \\
\left(0.005^{* *}\right)\end{array}$ & $\begin{array}{l}22.87 \\
\left(0.008^{* *}\right)\end{array}$ \\
\hline \multicolumn{4}{|l|}{ Controls } \\
\hline Democracy & $\begin{array}{l}1.04 \\
\left(0.000^{* * *}\right)\end{array}$ & $\begin{array}{l}1.04 \\
\left(0.000^{* * *}\right)\end{array}$ & $\begin{array}{l}1.04 \\
\left(0.000^{* * *}\right)\end{array}$ \\
\hline State AGE & $\begin{array}{l}0.99 \\
(0.000 * * *)\end{array}$ & $\begin{array}{l}0.99 \\
\left(0.001^{* * *}\right)\end{array}$ & $\begin{array}{l}0.98 \\
(0.000 * * *)\end{array}$ \\
\hline $\begin{array}{l}\text { Human \& Labor Rights } \\
\text { (ref.: Rule of LaW) }\end{array}$ & $\begin{array}{l}2.41 \\
\left(0.000^{* * *}\right)\end{array}$ & $\begin{array}{l}2.43 \\
\left(0.000^{* * *}\right)\end{array}$ & $\begin{array}{l}2.54 \\
\left(0.000^{* * *}\right)\end{array}$ \\
\hline SECURITY (ref.: & 6.08 & 6.04 & 3.04 \\
\hline Rule of LaW) & $\left(0.000^{* * *}\right)$ & $\left(0.000^{* * *}\right)$ & $\left(0.000^{* * *}\right)$ \\
\hline ENVIRONMENT (ref.: & 2.66 & 2.61 & 2.12 \\
\hline Rule of LAW) & $\left(0.000^{* * *}\right)$ & $\left(0.000^{* * *}\right)$ & $\left(0.000^{* * *}\right)$ \\
\hline COLONIAL PAST & $\begin{array}{l}0.81 \\
(0.057 \cdot)\end{array}$ & & \\
\hline ReLigion (Muslim) & $\begin{array}{l}0.89 \\
(0.33)\end{array}$ & & \\
\hline RRIS & & $\begin{array}{l}2251.0 \\
\left(0.000^{* * *}\right)\end{array}$ & \\
\hline Signature & & & $\begin{array}{l}3.09 \\
\left(0.000^{* * *}\right)\end{array}$ \\
\hline LRT & 513.3 & 602.7 & 943.5 \\
\hline$(p)$ & (0) & (0) & (0) \\
\hline Wald test & 292.3 & 345.5 & 496 \\
\hline & (0) & (0) & (0) \\
\hline Robust (score) logrank test & 97.98 & 103.8 & 117.8 \\
\hline$(p)$ & $(0)$ & $(0)$ & $(0)$ \\
\hline No. Observations & 38490 & 38490 & 38490 \\
\hline No. Events & 2123 & 2123 & 2123 \\
\hline No. States & 152 & 152 & 152 \\
\hline Period & 1949-2000 & $1949-2000$ & $1949-2000$ \\
\hline
\end{tabular}

Table 7: Additional models based on subsample of US non-ratified treaties.

Notes: Each cell entry $[\exp (\operatorname{coef})]$ is the exponential of the coefficient which is the hazard ratio (HR). The likelihood ratio test assumes independence of observations within a cluster (country); the Wald and robust score tests do not. ${ }^{* * *} p|z|=<.001,{ }^{* *} p|z|=<.01,{ }^{*} p|z|=<.05$.

$1 \quad$ We also checked whether particular groupings of countries might be artificially 2 driving the results. In particular, because European states are well-known sup3 porters of multilateralism, we tested for the "European" effect by controlling for 
1 whether a state is located in Europe ${ }^{65}$ (Table 8, model A4; based on subsample 2 of US non-ratified treaties) and by excluding European states from the data sam-

ple. Our results indicate that their support is not just because these states are "European" - as in "normative Europe" - but also because of their position as powerful and independent states. Similarly, controlling for (or excluding) alternative groupings of countries such as G8 and G20 did not change our major findings. Finally, we also found a positive effect of being a New Democracy on treaty ratification but, again, this did not change the central findings (Table 8, model A5).

Third, we refitted our models based on alternative measures of INDEPENDENCE and Power. Because the IndePendence measure (as used in models shown in Table 2) captures relative rather than absolute trade importance, we constructed an alternative variable of DEPENDENCE (measured in terms of a state's trade with the US as a proportion of its GDP). ${ }^{66}$ While the effect of DEPENDENCE is the opposite of INDEPENDENCE (as expected), the general finding of the model is confirmed (see Table 8, models A6 and A7). For alternative measures of Power, we used the separate dimensions (economic, military and human capital) of our index, the Composite Index of National Capability (CINC) ${ }^{67}$ and GDP. ${ }^{68}$ While military capabilities - measured as CINC or the military component of our PoweR index ${ }^{69}$ - played no statistically significant role in our models, results based on GDP (see Table 8, model A7) and the other two dimensions of the PowER index - economic power and social and human capital - were important but did not change the results substantively. This not only confirms that military capabilities were not having undue influence, it suggests a need for caution in using military

\footnotetext{
${ }^{65}$ Europe is correlated with Power at 0.53 .

${ }^{66}$ The negative correlation between INDEPENDENCE and DEPENDENCE is relatively strong at -0.69. Both variables correlate weakly with Power (IndePendence: 0.066 and DePendence: $0.041)$.

${ }^{67}$ Correlates of War Project 2005.

${ }^{68}$ World Bank 2007. The correlation between Power and CINC is 0.351, and between Power and GDP is 0.737 .

${ }^{69} \mathrm{CINC}$ and the military dimension of our POWER index are correlated at 0.909 .
} 


\begin{tabular}{|c|c|c|c|c|}
\hline & $\begin{array}{l}\text { Model A4 } \\
\exp (\text { coef }) \\
(p)\end{array}$ & $\begin{array}{l}\text { Model A5 } \\
\exp (\text { coef }) \\
(p)\end{array}$ & $\begin{array}{l}\text { Model A6 } \\
\exp (\text { coef }) \\
(p)\end{array}$ & $\begin{array}{l}\text { Model A7 } \\
\exp (\text { coef }) \\
(p)\end{array}$ \\
\hline POWER & $\begin{array}{l}0.07 \\
\left(0.022^{*}\right)\end{array}$ & $\begin{array}{l}0.06 \\
\left(0.009^{* *}\right)\end{array}$ & $\begin{array}{l}2.22 \\
(0.072)\end{array}$ & \\
\hline INDEPENDENCE & $\begin{array}{l}0.01 \\
\left(0.019^{*}\right)\end{array}$ & $\begin{array}{l}0.01 \\
\left(0.003^{* *}\right)\end{array}$ & & \\
\hline DEPENDENCE & & & $\begin{array}{l}147500.0 \\
\left(0.013^{*}\right)\end{array}$ & $\begin{array}{l}11.22 \\
(0.058)\end{array}$ \\
\hline GDP & & & & $\begin{array}{l}1.07 \\
\left(0.011^{*}\right)\end{array}$ \\
\hline POWER*INDEPENDENCE & $\begin{array}{l}26.22 \\
\left(0.021^{*}\right)\end{array}$ & $\begin{array}{l}56.81 \\
(0.001 * * *)\end{array}$ & & \\
\hline Power*DePENDEnce & & & $\begin{array}{l}0.0001 \\
\left(0.009^{*}\right)\end{array}$ & \\
\hline GDP*DEPEndENCE & & & & $\begin{array}{l}0.71 \\
\left(0.02^{*}\right)\end{array}$ \\
\hline \multicolumn{5}{|l|}{ Controls } \\
\hline Democracy & $\begin{array}{l}1.04 \\
\left(0.000^{* * *}\right)\end{array}$ & $\begin{array}{l}1.04 \\
\left(0.000^{* * *}\right)\end{array}$ & $\begin{array}{l}1.04 \\
\left(0.000^{* * *}\right)\end{array}$ & $\begin{array}{l}1.04 \\
\left(0.000^{* * *}\right)\end{array}$ \\
\hline State AGE & $\begin{array}{l}0.98 \\
(0.000 * * *)\end{array}$ & $\begin{array}{l}0.99 \\
\left(0.001^{* * *}\right)\end{array}$ & $\begin{array}{l}0.99 \\
\left(0.007^{* *}\right)\end{array}$ & $\begin{array}{l}0.99 \\
\left(0.002^{* *}\right)\end{array}$ \\
\hline $\begin{array}{l}\text { HUMAN \& Labor Rights } \\
\text { (ref.: Rule of LaW) }\end{array}$ & $\begin{array}{l}2.43 \\
\left(0.000^{* * *}\right)\end{array}$ & $\begin{array}{l}2.43 \\
\left(0.000^{* * *}\right)\end{array}$ & $\begin{array}{l}2.52 \\
\left(0.000^{* * *}\right)\end{array}$ & $\begin{array}{l}2.48 \\
\left(0.000^{* * *}\right)\end{array}$ \\
\hline SECURITY (ref.: & 6.13 & 6.14 & 6.43 & 6.24 \\
\hline Rule of LAW) & $(0.000 * * *)$ & $(0.000 * * *)$ & $\left(0.000^{* * *}\right)$ & $\left(0.000^{* * *}\right)$ \\
\hline ENVIRONMENT (ref.: & 2.69 & & 2.94 & \\
\hline Rule of LaW) & $\left(0.000^{* * *}\right)$ & $\left(0.000^{* * *}\right)$ & $\left(0.000^{* * *}\right)$ & $\left(0.000^{* * *}\right)$ \\
\hline EUROPE & $\begin{array}{l}1.68 \\
\left(0.000^{* * *}\right)\end{array}$ & & & \\
\hline New Democracy & & $\begin{array}{l}1.29 \\
\left(0.048^{*}\right)\end{array}$ & & \\
\hline $\begin{array}{l}\text { LRT } \\
(p) \\
\text { Wald test } \\
(p) \\
\text { Robust (score) logrank test } \\
(p)\end{array}$ & $\begin{array}{l}529.2 \\
(0) \\
294.8 \\
(0) \\
97.85 \\
(0) \\
\end{array}$ & $\begin{array}{l}508.6 \\
(0) \\
295.2 \\
(0) \\
98 \\
(0) \\
\end{array}$ & $\begin{array}{l}403.9 \\
(0) \\
288.8 \\
(0) \\
96.03 \\
(0)\end{array}$ & $\begin{array}{l}404.1 \\
(0) \\
288.5 \\
(0) \\
96.06 \\
(0)\end{array}$ \\
\hline No. Observations & 38490 & 38490 & 32957 & 33355 \\
\hline No. Events & 2123 & 2123 & 1864 & 1890 \\
\hline No. States & 152 & 152 & 151 & 153 \\
\hline Period & $1949-2000$ & $1949-2000$ & $1960-2000$ & $1960-2000$ \\
\hline
\end{tabular}

Table 8: Additional models based on subsample of US non-ratified treaties.

Notes: Each cell entry $[\exp (\operatorname{coef})]$ is the exponential of the coefficient which is the hazard ratio (HR). The likelihood ratio test assumes independence of observations within a cluster (country); the Wald and robust score tests do not. ${ }^{* * *} p|z|=<.001,{ }^{* *} p|z|=<.01,{ }^{*} p|z|=<.05$. 
measures to capture influence and to consider power in more comprehensive terms in general international issues.

Fourth, we also excluded observations for Canada and Mexico which might have been consequential outliers that are powerful but dependent. The results did not change.

Fifth, we confirmed our results for the key POWER*INDEPENDENCE combination based on the original smaller IATP sample and on several different subsets of our data set excluding individual issue areas from the full sample. In addition, we refitted model 5 from Table 2 (for treaties that the US ratified quickly in the year of treaty adoption or the year after) with a slightly extended sample of treaties. Economic treaties are not included in the IATP sample, so we added four key post-war economic agreements to our sample: the Articles of Agreement of the International Monetary Fund (1945), the International Bank for Reconstruction and Development Articles of Agreement (1945), the GATT (1948) ${ }^{70}$ and the Agreement Establishing the WTO (1995). The first three treaties were adopted at the peak of American dominance and the WTO Agreement was also adopted under a strong show of US power through the "single undertaking". ${ }^{71}$ The extended model 5 both confirmed the results of initial model 5 and improved them by yielding statistically significant effects for the interaction term and independence.

Finally, to assess the robustness of our results with regard to particular treaties, we ran a bootstrap simulation for model 3 from Table 2. Sampling randomly with replacement on treaties in 199 iterations, we resampled the original data. The results of the simulation for PoweR*INDEPENDENCE are presented in Figure 3, and confirm that the interaction has a significant and consistent effect on the likelihood of ratification (zero is outside the confidence bounds).

\footnotetext{
${ }^{70}$ When working with the extended treaty sample, we allowed for the right-censorship of the GATT which expired in 1994.

${ }^{71}$ Steinberg 2002.
} 


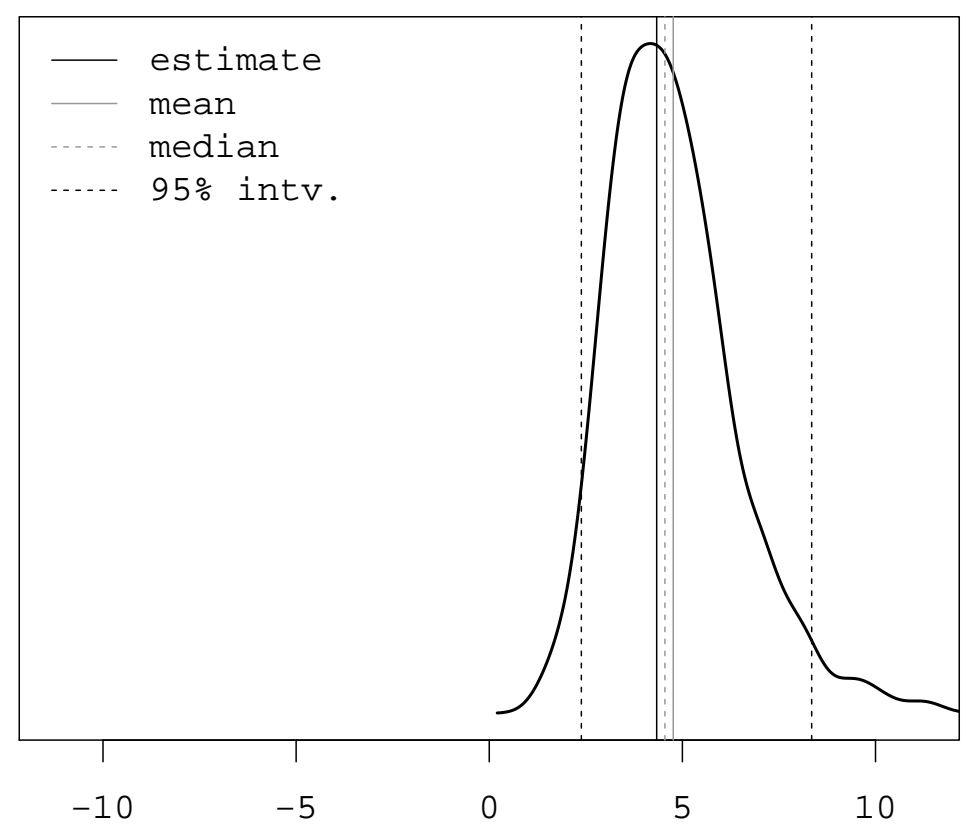

Figure 3: Bootstrap simulation result for PoweR*IndePendence.

\section{Control variables}

2 The controls included in models presented in Table 2 behave largely as expected.

3 Democracies have a significant tendency to be strong multilateralists: A fully

4 democratic state is between 2.22 (model 6) and 3.14 (model 5) times more likely

5 to ratify a multilateral treaty than a highly autocratic regime. ${ }^{72}$ Improvement on

6 the polity scale by one unit increases a state's ratification likelihood between $4 \%$

7 (models 3 and 6$)$ and 6\% (model 5).

8 State AGE has a highly significant negative effect on ratification (with the 9 exception of model 5 based on the subsample of US ratified treaties, where it is 10 no longer significant). This confirms previous findings that newer states seek to

11 establish their good citizenship in the international community by means of speedy 12 treaty ratifications.

13 Results for the issue area variables are not consistent across models and differ

${ }^{72}$ Calculated as $\exp \left(\operatorname{coe} f_{\text {Democracy }} * 10\right) / \exp \left(\operatorname{coe} f_{\text {Democracy }} *(-10)\right)$. 
according to whether the US has or has not ratified. Estimations based on the full sample and on the subsample of treaties that the US has not ratified (models 2 and 3) show all issue areas affecting the likelihood of ratification positively as compared to the Rule of LaW baseline (although the effect for Human \& Labor Rights is statistically insignificant). Following model 2, Environment seems to matter most: The ratification of an environmental treaty is $90 \%$ more likely than the ratification of a HUMAn \& LABOR Rights treaty, and $28 \%$ more likely than that of a Security treaty. ${ }^{73}$ When the US does not ratify, Security issues produce the strongest effects. Then the propensity of ratifying a security treaty is 2.27 times higher than for an Environmental treaty and 2.55 times higher than a Human \& Labor RIghts treaty. When the US ratifies, issue areas matter less and are less stable. Security issues yield the most consistent results. When the US ratifies a security treaty, it slows the pace at which the other states ratify by $47 \%$ (and by $77 \%$ when US ratifies immediately and by $41 \%$ when US ratifies later). Similarly, the likelihood of ratifying a Human \& LABOR Rights treaty decreases by $51 \%$ when the US does not participate ( $50 \%$ when the US joins later).

\footnotetext{
${ }^{73}$ Calculates as $\exp \left(\operatorname{coe} f_{\text {Environment }}\right) / \exp \left(\operatorname{coe} f_{\text {Human }} \&\right.$ Labor Rights $)$.
} 